\title{
41. Masal ve efsanelerde değerler eğitimi: Muş ili örneği
}

\section{Süleyman AYDENIZ'}

\begin{abstract}
APA: Aydeniz, S. (2021). Masal ve efsanelerde değerler eğitimi: Muş ili örneği. RumeliDE Dil ve
\end{abstract} Edebiyat Araştırmaları Dergisi, (23), 636-659. DOI: 10.2900o/rumelide.949511.

\section{$\ddot{\mathbf{O} z}$}

$\mathrm{Bu}$ çalışmada Muş yöresine ait masal ve efsanelerin değer eğitimi açısından incelenmesi amaçlanmıştır. Bu bağlamda Yavuz (2006), Köse (2004), Aksu (2010) tarafından kaleme alınan Muş yöresine ait masallar ve Ekmekçi (2020)'nin eserinde geçen Muş efsaneleri, önce kök değerler daha sonra da bu değerlerin dışında yer alan değerler bağlamında ele alınmıştır. Çalışmada "temel nitel araştırma” deseni kullanılmıştır. Çalışmanın inceleme materyalleri, ifade edilen 4 tezde yer alan metinlerdir. Böylece Muş yöresine ait toplam 127 masal ve 105 efsane incelenmiştir. Çalışmada doküman incelemesine göre elde edilen veriler, içerik analiziyle çözümlenmiş, sıklık açısından değerlendirilmiş ve yorumlanmıştır. Çalışma sonunda Muş yöresi masal ve efsanelerinde kök değerlerin tamamına ait örneklerin bulunduğu ve en çok yardımseverlik (53), sevgi (39), dürüstlük (16), sabır (15), dostluk (14), adalet (13), öz denetim (7) kök değerlerine yer verildiği tespit edilmiştir. Masal ve efsanelerde kök değerlerin dışında ise 30 farklı değerin olduğu saptanmıştır. Bu değerlerde en fazla dini değerlere duyarlılı (73), estetik (56), azimli olma (30), iyilik etme (30), çalışkanlık (20), aile birliğine/ bağlarına önem verme (19), cömertlik/ cömert olma (17), geleneksellik (16), cesaret/ cesur olma (14) ve nezaket (14) değerlerine yönelik örneklerin olduğu görülmüştür. Bu sonuçlar Muş yöresi masal ve efsanelerinin değerler eğitimi açısından zengin olduğunu göstermektedir. Çalışmanın sonunda öneriler sunulmuştur.

Anahtar kelimeler: Muş masalları, Muş efsaneleri, kök değerler, değer eğitimi

\section{Values education in tales and legends: Sample of city of Muş}

\begin{abstract}
In this study, it was aimed to examine the tales and legends of Muş province in terms of values education. In this respect, the tales of Muş province written by Yavuz (2006), Köse (2004), Aksu (2010) and the legends of the city mentioned in the work of Ekmekçi (2020) were first discussed in the context of root values and then values outside these values. The "basic qualitative research" design was used in the study. The research materials of the study are the texts in the 4 theses expressed. Thus, a total of 127 tales and 105 legends belonging to the province of Muş were examined. The data obtained according to the document analysis were analyzed with content analysis, evaluated and interpreted in terms of frequency. At the end of the study, it was established that there are examples of all of the root values in the tales and legends of the city of Muş and that the root values helpfulness (53), love (39), honesty (16), patience (15), friendship (14), justice (13), self-control (7) are included the most. It was determined that there are 30 different values in fairy tales and legends other than the root values. In these values, sensitivity to religious values (73), aesthetics (56), determination (30), doing a favour (30), diligence (20), giving importance to family
\end{abstract}

Dr. Öğr. Üyesi, Muş Alparslan Üniversitesi, Eğitim Fakültesi, Türkçe ve Sosyal Bilimler Eğitimi Bölümü, Türkçe Eğitimi ABD (Muş, Türkiye), s.aydeniz@alparslan.edu.tr, ORCID ID: o0oo-0oo1-9277-529X [Araştırma makalesi, Makale kayıt tarihi: 03.03.2021-kabul tarihi: 20.06.2021; DOI: 10.29000/rumelide.949511]

\section{Adres $\mid$ Address}

RumeliDE Dil ve Edebiyat Araşttrmaları Dergisi $\quad$ RumeliDE Journal of Language and Literature Studies Osmanağa Mahallesi, Mürver Çiçeği Sokak, No:14/8 Osmanağa Mahallesi, Mürver Çiçeği Sokak, No:14/8

Kadıköy - İSTANBUL / TÜRKIYE 34714 Kadıköy - ISTANBUL / TURKEY 34714 e-posta: editor@rumelide.com

e-mail: editor@rumelide.com,

tel: +90 505 7958124, +90 216773 o 616 phone: +90 505 7958124, +90 2167730616 
unity / ties (19), generosity / being generous (17), traditionalism (16), bravery / being brave (14) and kindness (14) were seen to be examples of values. These results show that the tales and legends of Muş province are rich in values education. Suggestions are presented in the ending of the study.

Keywords: Muş tales, Muş legends, root values, values education

\section{Giriş}

İnsanlığın bilinen tarihi içinde genel olarak, devlet olmasa bile, insanların topluluk halinde yaşadıkları bilinen bir gerçektir. Devlet olduğunda zaten kurumsal bir yapının varlığı ortada demektir. İnsanların bireysel yaşamlarını devam ettirmek için kendilerine yabancı veya düşman gördükleri hemcinslerinin ve tabiat içinde diğer canlıların tehditlerini bertaraf etmeleri birbirlerinin güçlerinden faydalanmaları lazımdır. Bu da topluluk veya toplum olmalarını gerektirir. Topluluğun veya toplumun devam etmesi için de belli kurallar vardır. Bu kurallar son zamanlarda yazılı hale getirilse de önceleri yazılı halde değildir. Yazılı kurallar oluşturulana kadar önceki kurallar, sözlü olarak nesilden nesile aktarılmış ve uygulanmıştır. Aynı zamanda yazılı kurallara da örneklik teşkil etmiştir. Günümüzde toplum açısından önemli olan birçok kural, yazılı olmasa da gelenek, örf ve adet olarak uygulanmaya devam edilmektedir. Bu kuralların bir kısmı kanun, yönetmelik, yönerge vb. şekillerde yazılı olarak görülmektedir. Daha fazla oranda bir kısmı ise yazılmamış kurallardır. Toplumlarda bu kuralların önemi yadsınamaz. İşte bu kuralların esası 'değerler'dir. Değerler genel kabul görmüş kurallardır. İnsanların yakınlarına, diğer insanlara ve hatta kendisine karşı olan sorumlulukları vardır. $\mathrm{Bu}$ sorumlulukların bir kısmını 'değerler' oluşturmaktadır.

Alan yazında değer kavramı farklı araştırmacılar tarafından farklı şekillerde tanımlanmıştır. Halstead ve Taylor (2000: 169) değer kavramını "davranışa ilişkin genel rehber olarak hareket eden ilkelere ve temel inançlara, belirli eylemlerin iyi veya arzulanan standartlarına atıfta bulunmak için kullanılan gerçeklikler"; Oğuzkan (1993) "bir varlığın, ruhsal, toplumsal, ahlaki ya da estetik yönden taşıdığı düşünülen yüksek ve yararlı nitelik"; Akbaş (2004) ise "sosyal bir varlık olan bireyin sosyal çevresiyle etkileşimi sonucunda özümsediği ve davranışlarına şekil veren belirli kurallar” olarak tanımlamışlardır.

Değer kavramının önemli yer tuttuğu alanlardan biri de eğitimdir. Bu eğitim alanlarından biri de Türkçe dersi ve öğretim programlarıdır. Daha önceki Türkçe Dersi Öğretim Programlarında değerler başlı̆ı adı altında bir bilgi bulunmamaktadır. Yaşaroğlu (2015), değerlerin; 2005/2009 Türkçe Dersi Öğretim Programının içinde müstakil bir başlık ve bölüm olmamasına rağmen 'programın temel özellikleri, genel amaçlar, temel beceriler, öğrenme alanları ve kazanımlar' adı altında yer aldığını belirtir. MEB (2017), "Müfredatta yenileme ve değişiklik çalışmalarımız üzerine" adı altında bir basın açıklaması yaparak 10 kök değeri ve alt değerlerini içeren değerler tablosunu kamuoyuna sunmuştur. Bundan sonra diğer dersler gibi Türkçe Dersi Öğretim Programı (2018) içinde de 2018 yllından itibaren bu değerler tablosu yerini almıştır. Ders kitaplarındaki metinler, bölümler ve kazanımlar buna göre hazırlanmıştır. Her sınıfın ders kitabında ‘değerlerimiz' diye bir bölüm de yer almaya başlamıştır.

Karagöz (2017), Türkçe dersiyle değerler ilişkisini "Türkçe, değerler eğitiminin etkili ve kapsamlı bir şekilde gerçekleştirildiği temel derstir. Değerler eğitimi çerçevesinde engin kültürel birikimden beslenen, değerlerle donanmış sözlü kültür birikiminin öğrencilerle buluşturulması gereklidir.” biçiminde ifade etmektedir.

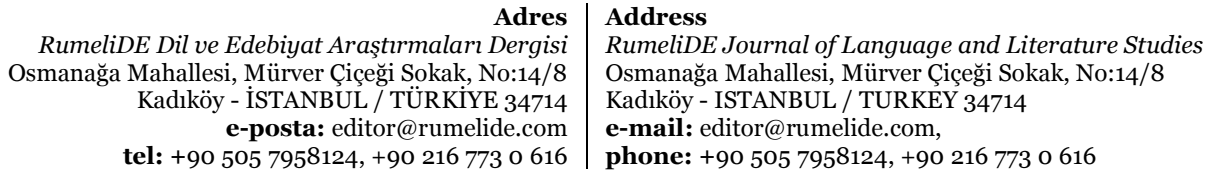

RumeliDE Dil ve Edebiyat Araştırmaları Dergisi -posta: editor@rumelide.com tel: +90 505 7958124, +90 2167730616
Address

Osmanağa $\mathrm{Mat}$

e-mail: editor@rumelide.com

phone: +90 5057958124 , +90 2167730616 
Yeni nesillere toplumun ve ulusun değerlerinin aktarılmasında halk kültürünün birçok türünden yararlanılabilir. Bu türlerden bazıları da masal ve efsanelerdir. Ilıcak ve Başoğlu (2018), masalların eğitici yönünü anlatırken "Masallar eğitici, öğretici ve ders verici niteliktedir. Çocuklar; doğru ile yanlışı, iyiliğin ödülsüz, kötülüğün ise cezasız kalmayacağını masallar aracılığıyla öğrenmektedir. Bir bakıma masallar "iyi bir kişi” olmayı öğütleyen ürünlerdir." diye ifade etmişlerdir.

Alan yazında masal türünün değerler eğitimi açısından incelendiği çalışmalar bulunmaktadır (Kasımoğlu, 2010; Yeniasır, 2015; Kılcan, 2016; Özcan, 2017; Akkaya, 2017; Karatay, 2007; Kardaş, 2020). Masalların dışında değer eğitiminin verilebileceği türlerden biri de efsanelerdir. Max Luthi; efsanenin ahlaki, objektif, zaman ve mekana bağlı bir anlatım türü olduğunu ve her iki dünyayı bir arada bulundurduğunu (Kardaş, 2020) belirtmektedir. Efsaneler ahlaki değerleri barındırmaktadır. Toplumun hafızası denilebilecek bu halk kültürü ürünlerinin (masal-efsane) çeşitli yönlerden incelendiği birçok çalışma bulunmaktadır. Ancak bu türlerden özellikle efsanenin eğitim ve değer eğitimi bağlamında incelendiği çalışma sayısı azdır. Değer eğitimi açısından masallarla ilgili çalışma sayısının fazla olmasına rağmen efsanelerle ilgili değer eğitimi çalışmalarının daha az olduğu tespit edilmiştir.

Efsaneleri değer eğitimi bağlamında ele alan Çiftçi ve Sayır (2019), "Tarihi, çok eskilere dayanan efsanelerin sözlü kültür ürünleri arasında önemli bir yeri olduğunu; dinî, sosyal, ahlaki ve eğitsel boyutları bulunan efsanelerin, çeşitli açllardan incelenmesinin mümkün olduğunu” vurgulamışlardır. Güven (2014), Türk efsanelerini değerler eğitimi bakımından incelerken sadece Türkiye sahasını değil Türkçe konuşulan diğer sahaları da ele almıştır. Alan yazında bu iki örnek dışında efsaneleri değer bakımından inceleyen başka çalışma tespit edilememiştir. Bunun yanı sıra Muş merkez ve ilçelerindeki masal ve efsaneleri değer eğitimi açısından inceleyen herhangi bir çalışma bulunamamıştır. Çalışmanın bu yönüyle özgün olduğu ve alana katkı sunduğu söylenebilir.

\section{Yöntem}

Bu çalışma, nitel araştırma yaklaşımlarından 'temel nitel araştırma' deseni bağlamında ele alınmıştır. Merriam (2013)'a göre temel nitel araştırma, yorumlamanın ön planda olduğu bir nitel çalışmadır ve bu araştırmalarda veriler gözlem, doküman analizi veya görüşme yoluyla toplanmaktadır. $\mathrm{Bu}$ bağlamda çalışmada, dört eser (tez) değer eğitimi açısından ele alınmıştır. Bu tür çalışmalarda yorumlayıcı bir yaklaşım da ön plandadır. Bu yüzden çalışmada 'temel nitel araştırma' modeli tercih edilmiştir.

\section{Verilerin toplanması}

$\mathrm{Bu}$ araştırmada veriler, doküman incelemesine göre toplanmıştır. Creswell (2005)'e göre dokümanlar nitel araştırmalarda önemli bir veri kaynağıdır. Doküman incelemesi alan yazında çeşitli isimler almaktadır. Bu isimlerden bazıları belgesel gözlem veya belgesel taramadır (Çepni, 2012). Belgesel taramalar herhangi bir amaç için önce kaynakları toplama, okuma, not alma ve son olarak da değerlendirme aşamalarından oluşur (Karasar, 2007).

Çalışmada kuramsal alt yapıyı oluşturmak için geniş bir alan yazın taraması yapılmıştır. Konuyla ilgili bilimsel ve akademik çalışmalar ayrıntılı olarak incelenmiştir. Daha sonra çalışmanın materyallerini oluşturan Muş ili ile ilgili yapılmış tezlerdeki masal ve efsaneler iki defa okunmuş, masallar ve efsanelerde doğrudan veya dolaylı olarak değer ifade eden cümle veya paragraflar tespit edilmiş ve

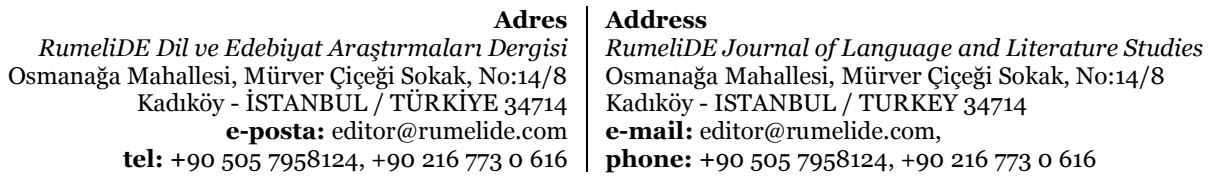


işaretlenmiştir. Böylece tespiti yapılan değerler sınıflandırılmış ve notlar (masal - efsane isimleri ve değerin geçtiği sayfa vb.) alınmıştır. Çalışma bulguları bu bağlamda oluşturulmuştur.

\section{İncelenen dokümanlar/çalışma materyalleri}

Çalışmada incelenen materyallere yönelik bilgiler aşă̆ıda verilmiştir:

Yavuz, M. Ş. (2006). Muş Masalları Üzerine Bir Araştırma. (Yayımlanmamış Yüksek Lisans Tezi),Yüzüncü Yıl Üniversitesi Sosyal Bilimler Enstitüsü, Van.

Ekmekçi, D. N. (2020). Muş Efsaneleri İnceleme Metin. (Yayımlanmamış Yüksek Lisans Tezi), Akdeniz Üniversitesi Sosyal Bilimler Enstitüsü, Antalya.

Köse, A. (2004). Muş İli Malazgirt İlçesinde Anlatılan Masallartn Çocuk Eğitimine Katkısı. (Yayımlanmamış Yüksek Lisans Tezi),Selçuk Üniversitesi Sosyal Bilimler Enstitüsü, Konya.

Aksu, B. (2010). Muş Çocuk Folkloru. (Yayımlanmamış Yüksek Lisans Tezi),Yüzüncü Yıl Üniversitesi Sosyal Bilimler Enstitüsü, Van.

Muş ve ilçeleri adına halk kültürünü yansıtan tezler incelenmiş ve derlenen metinlere ulaşılmıştır. Çalışmaya uygun olduğuna karar verilen 4 yüksek lisans tezinde yer alan masal ve efsane metinleri incelemeye tabi tutulmuştur. Bu tezlerdeki farklı olan masal ve efsaneler ayrı ayrı incelenip birbirinin tekrarı olan metinler çıkarıldıktan sonra kalan 55 masal, 101 efsane ve Malazgirt masallarını konu edinen tezdeki 72 masal ile toplamda 127 masal ve 101 efsane, içerdiği değerler açısından ele alınmıştır. Mirza Muhammed, Kızıl Ziyaret, Üç Bacı, Üç Kardeş, Satın Alınan Öğüt, Kurnaz Tilki ve Büyük Hamurpet Gölü adlı metinlerin benzer isimli oldukları ancak içeriklerinin farklı olduğu tespit edilmiştir. Söz konusu dokümanlarda 30 masal, 97 efsane metninin bir sayfadan daha kısa olduğu saptanmıştır. Çalışma sonunda, araştırmada kullanılan masal ve efsanelere ait bilgiler EK başlığı altında sunulmuştur.

\section{Verilerin analizi ve yorumlanması}

Çalışmada veriler içerik analizine göre değerlendirilmiştir. Yıldırım ve Şimşek (2008) içerik analizinde verilerin ilk olarak kavramsal hale getirildiğini ve daha sonra bu kavramların düzenlendiğini son olarak da temaların tespit edildiğini belirtmektedir.

Çalışmaya konu olan masal ve efsaneler çalışma süresince araştırmacı tarafından iki kez okunmuş ve kodlanmıştır. Böylece masal ve efsanelerde yer alan (10 kök değer dışında) değer olduğu düşünülen 48 kavram tespit edilmiştir. Söz konusu kavramların değer olup olmadıklarının saptanması için alan yazın incelenmiş ve özellikle masal ve efsane konularındaki değerler eğitimi hakkında yapılan çalışmalar göz önünde bulundurulmuştur. Daha sonra tespit edilen kavramlar 5 alan uzmanının görüşüne sunulmuş, kavramların değer olarak kabul edilip edilmemesi ile ilgili değerlendirmeleri alınmıştır. Alan uzmanlarının değerlendirmeleri doğrultusunda 18 kavram listeden çıkarılmış, alan uzmanlarının üzerinde ittifak ettikleri 30 kavram bu masallardan elde edilen değerler olarak kabul edilmiştir. Son olarak kabul edilen değerler, 2018 yılında yayımlanan öğretim programlarında ifade edilen kök değerler dikkate alınarak 'Kök Değerler' ve 'Diğer Değerler' (kök değerler dışında kalanlar) olarak temalaştırılmış ve yorumlanmıştır.

\section{Bulgular}

$\mathrm{Bu}$ bölümde çalışmanın verilerinden elde edilen bulgulara yer verilmiştir. Çalışmanın bulguları iki ayrı tablo halinde ele alınmış ve yorumlanmıştır. Bulgularda tespit edilen değerlerin sıralanmasında sıklık

\begin{tabular}{|c|c|}
\hline & \\
\hline eliDE Dil ve Edebiyat Araşttrmaları De & E Journal of Language and Literature Studies \\
\hline 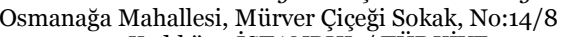 & Mahallesi, Mürver Çiçeği Sokak, No:14/8 \\
\hline Kadıköy $-\mathrm{I}$ & ISTANBUL / TURKEY 34714 \\
\hline $\begin{array}{r}\text { e-posta: editor } \\
\text { tel: }+905057958124,+9\end{array}$ & $\begin{array}{l}\text { editor@rumelide.com, } \\
\text { +90 505 7958124, +90 } 2167730616\end{array}$ \\
\hline
\end{tabular}


değeri göz önüne alınmıştır. Çalışmada "M" kodu ile Muş masalları, "E” kodu ile Muş efsaneleri ve "MA" kodu ile de Malazgirt masalları ifade edilmiştir.

Tablo 1. Muş yöresine ait masal ve efsanelerde tespit edilen kök değerler, değerlerin frekanslari ve yer aldiklari masal ve efsaneler.

\begin{tabular}{|c|c|c|c|c|}
\hline Tema 1 & $\begin{array}{l}\text { Sira } \\
\text { No }\end{array}$ & Değerler & $(f)$ & Değerlerin Yer Aldığı Masallar ve Efsaneler \\
\hline \multirow{10}{*}{$\begin{array}{l}\text { Kök } \\
\text { Değerler }\end{array}$} & 1 & Yardımseverlik & 53 & $\begin{array}{l}\text { M12, M13, M14, M15, M18, M21, M22, M24, M25, M29, } \\
\text { M30(2), M34, M37(3), M38(2), M42, M43, M45, M49, M50, } \\
\text { E33, E35, E45, E73, E76, MA13, MA17, MA18(2), MA19, } \\
\text { MA20, MA21(4), MA24, MA28, MA30, MA31(2), MA41(2), } \\
\text { MA42, MA43, MA45, MA46, MA52, MA60, MA62, MA66. }\end{array}$ \\
\hline & 2 & Sevgi & 39 & $\begin{array}{l}\text { M37, M50(3), M52, M54(2), E8, E19, E22, E25, E30, E48, } \\
\text { E52, E56, E57, E58, E59, E60, E83, MA3, MA11, MA12, } \\
\text { MA14, MA17, MA18, MA24, MA30, MA41, MA43, MA48, } \\
\text { MA49, MA54, MA55, MA58, MA64(2), MA67, MA72. }\end{array}$ \\
\hline & 3 & Dürüstlük & 16 & $\begin{array}{l}\text { M19, M43, M44, M46, E25, MA12, MA19(2), MA20, } \\
\text { MA27(2), MA50, MA53, MA58, MA59, MA68. }\end{array}$ \\
\hline & 4 & Sabır & 15 & $\begin{array}{l}\text { M39, M50, M54, E25, E96, MA22, MA25, MA29, MA30, } \\
\text { MA53, MA54, MA56, MA57, MA58, MA72. }\end{array}$ \\
\hline & 5 & Dostluk & 14 & $\begin{array}{l}\text { M4, M8, M17, M22, M23, M25, M33, M38, M45(2), M47, } \\
\text { E25, MA21, MA25. }\end{array}$ \\
\hline & 6 & Adalet & 13 & $\begin{array}{l}\text { M15, M20(2), M30, M31, M38. MA12, MA39, MA41, MA48, } \\
\text { MA56, MA64, MA67. }\end{array}$ \\
\hline & 7 & Öz Denetim & 7 & M6, M47, MA15, MA26, MA30, MA38, MA47. \\
\hline & 8 & Saygl & 3 & $\mathrm{M}_{43}, \mathrm{M}_{51}, \mathrm{M}_{54}$ \\
\hline & 9 & Sorumluluk & 2 & M40, E88. \\
\hline & 10 & Vatanseverlik & 2 & E64, E66. \\
\hline
\end{tabular}

Tablo 1 incelendiğinde Muş yöresine ait masal ve efsanelerde kök değerlerin tamamına ait örneklerin yer aldığı tespit edilmiştir. Muş yöresinin masal ve efsanelerinin kök değerler bakımından zengin olduğu görülmektedir. Kök değerlerin toplam sayısı 164’tür. Yardımseverlik ve sevgi kök değerlerinin toplamının 92 olmasıyla değerlerin yarısından fazlasının bu iki değerde bulunması dikkat çekicidir.

Tablo 1'deki sonuçlara göre Muş ve Malazgirt masallarında ve Muş efsanelerinde en fazla yardımseverlik 53 kök değerine yer verildiği görülmektedir. Bu değeri sevgi (39), dürüstlük (16), sabır (15), dostluk (14), adalet (13), öz denetim (7) kök değerleri takip etmektedir. En az yer verilen kök değerler ise saygı (3), sorumluluk (2) ve vatanseverlik (2) değerleridir. Aşağıda kök değerlerin masal ve efsanelerde nasıl yer aldığına ilişkin örnekler yer almaktadır: 


\section{Yardımseverlik}

Yardımseverlik, toplum içindeki bireylerin hayatlarını devam ettirmesi için birbirlerinin ihtiyaçlarını gidermesi olarak tanımlanabilir. Muş yöresi masal ve efsanelerinde en çok yardımseverlik kök değerine yer verildiği saptanmıştır. Bu örneklerden bazıları şu şekildedir:²

"Anlaşmışler gidip getırmağa. Ayi tılkiye demiş:

"Sen çobani oyale men de koyıni alacam."

Tilki çobani oyalamış, ayi de gitmiş koyını yahalamış, getırmiş. Koyıni kesip kavurme yapmişler. Birazıni kurda vermişler, gerisini tenekeye koyıp kuyulamişler." (M18, Tilki-Ayl-Kurt, s.167)

“O değirmenin sahibi olan yaşlı bir adam çocuklarımı alıp onları beslemiş.” (MA18, Üç Kız Kardeş, s.123)

“Feyzo, kadına istediği yere onu götürebileceğini söyler.”(E33, ElkaFeyzo, s.79)

\section{Sevgi}

Muş yöresi masal ve efsanelerinde sevgi kök değerine çok fazla yer verilmiştir. Bu masal ve efsanelerde sevgi kök değeri; insanlar arasında sevgi, hayvanlar arasında sevgi veya insan ile hayvan ya da diğer varlıklar arasında sevgi şeklinde görülmektedir. Bu bakımdan masal ve efsanelerde sevginin her çeşidinin yer aldığı söylenebilir. Masal ve efsanelerde yer alan sevgi kök değerine ait bazı örnekler şu şekildedir:

"Ali, Fatik'e oni çoh sevdıgıni söler. Fatik de Aliyi sevmis. Bunlar evlenmaga kurar verirler. Tüm civar köyler, ekrebalar, tanıdıhler çagrılmış. Kirh gün, kırh gece dügün dernek yapılmiş. Ali ile Fatik evlenmişler. Ali, Fatik’i alı memleketıne götırmiş. Fatik, tek yadigari ve dosti olan tazistni de bereberınde götırmiș.” (M50, Babasının Yerine Askerlik Yapan Kız, s.231)

"Bir varmış bir yokmuş, evvellerde güzel şirin bir ev varmış. İçinde de çok mutlu mu mutlu bir çift varmış. Birbirlerini çok ama çok severlermiş.” (MA3, Hacı Ali, s.91)

"Rivayete göre karga, beyaz güle âşık olmuş. Beyaz gül, karganın yalvarışlarına, aşkına aldırış etmemiş.”(E19, Gül ve Karga, s.72)

\section{Dürüstlük}

Dürüstlük kök değerine Muş masal ve efsanelerinde 16 örnek tespit edilmiştir. Masallarda dürüstlük değeri genelde, açık sözlülük ve verdiği sözü tutma özelliği üzerinden aktarılmıştır. Masal ve efsanelerde yer alan dürüstlük kök değerine ait bazı örnekler şöyledir:

"Delikanli de:

"Nasl bize ne ana? Hani benim evlenme çă̆m gelmisti? Hani ben kimi istesem bana isteyecahtın?" demiş. Anasi ısrar etse de kurtılamamiş. Mecbur kadının evıne gitmis, kızıni istemaga." (M44, Peri Kızı, s.217)

"Padişah:

-O kzzı hiç istemesen daha iyi olur. Çünkü onun şartları çok ağırdır. Güzelliği kadar da nazı vardır demiş." (MA19, Kız Evladın Hikayesi, s.125)

"Çoban, kurtlarn bu yemininden sonra ikna olur ve koyunlarn teslim edip gider. Koyun sahiplerine durumu anlatnca sahip de kurtlarm verdikleri yemin ile ikna olur. Sahip, kurtlarm koyunlardan birini almasına izin verir. Çoban, kurtlarm yanina varı istedikleri bir koyunu alabileceklerini söyler." (E25, Kurban II, s.75)

2 Masal ve efsanelerden alınan örnek cümleler İstanbul Türkçesine çevrilmemis tezlerdeki özgün halleriyle verilmiștir. Örnek cümlelerin sonunda parantez içinde yer verilen kavramlar, ilgili masal ve efsanenin kodları ve isimleridir. Sonunda yazılan rakam ise masalın ilgili tezde geçen sayfa numarasıdır.

Adres | Address

RumeliDE Dil ve Edebiyat Araşttrmalar Dergisi $\quad$ RumeliDE Journal of Language and Literature Studies

Osmanağa Mahallesi, Mürver Çiçeği Sokak, No:14/8 Osmanağa Mahallesi, Mürver Çiçeği Sokak, No:14/8

Kadıköy - İSTANBUL / TÜRKIYE 34714 Kadıköy - ISTANBUL / TURKEY 34714

e-posta: editor

e-mail: editor@rumelide.com,

tel: +90 505 7958124, +90 2167730616 phone: +90 505 7958124, +90 2167730616 


\title{
Sabir
}

Sabır, kişinin hayatta karşılaştığı çeşitli zorluklar karşısındaki dayanma gücüdür. Muş yöresi masal ve efsanelerinde masal kahramanlarının çeşitli zorluklar karşısında irade gösterip sabırlı olma durumları ele alınmıştır (15). Masal ve efsanelerde yer alan sabır kök değerine ait bazı örnekler şu şekildedir:

\begin{abstract}
"Cengzeri dayisıni İslama davet eder. Kebuletmer. O de dayisıne savaş açar. Dayisının gücü çohtır, keleyi kuşatma altıne altr. Cengzeri hem keleye gizliden su geturdıgi için hem de erzah depoladıgi için uzun süre direnır. Aralerındeki savaş yedi yıl sürer.” (M39, Cengzeri, s.205)

"Derken günler geçmiş aylar gelmiş, mevsimler birbirini kovalayıp ilkbahara gelmişler.” (MA30, Yedi Ceylan, s.149)

“Adam, üç gün üç gece boyunca mezarm başından ayrlmaz.” (E25, Kurban II, s.75)

"Hızır, FekiyeTeyran’ ziyaret etmek için onun yaşadığı dağa çıkar. Fekiye Teyran'ın yanına varnca sorar: "Feki akıl nerededir?" Feki, bu soruya cevap veremez. Hizır, aynı soruyu tekrar sorar. Feki, yine cevap veremez. Üçüncü kez sorduğu soruya cevap alamayınca Hızır, "Feki akıl sabırdadir" der.”(E96, FekiyeTeyran, s.106)
\end{abstract}

\section{Dostluk}

Dostluk kavramı birçok özelliği içinde barındıran zengin bir kavramdır (Demir, 2019). İnsanlar, hayvanlar ve diğer canlılar arasında güçlü bir iletişimi ve sevgiyi ifade eder. Bu duruma rağmen Muş masallarında dostluk kök değerine ait örnekler orta sıralarda yer almaktadır. Toplamda 14 örnek tespit edilmiştir. Masal ve efsanelerde yer alan dostluk kök değerine ait bazı örnekler şu şekildedir:

"Meni de aranıze almursız? Arkadaş olah, beraber Hicaze gidah" demiş. Tikli ile Kurt beraber kurar vermişler, oni de aralerne almişler. Bu üç arkadaş beraber yürümişler.” (M47, Tilki-KurtKatır, s.225)

“Çok eski zamanlarda iki arkadaş varmış, bunlar Mert ile Namert imiş, bunlar bir kardeş gibi beraber gezerlermiş.” (MA25, Mert ile Namert, s.139)

"Rivayete göre bir adamın musâhibi ölmek üzeredir. Adam, son kez musâhibini görüp helalleşmek istese de cenazesine yetişemez. Köye vardiğında adamın ilk işi arkadaşını mezarına gitmek olur.”(E25, Kurban II, s.75)

\section{Adalet}

Adalet kavramı; sosyal yaşantının, aile hayatının ve insanlar arası ilişkilerin olumlu bir şekilde devam etmesi için gerekli olan bir kavramdır ve insanların haklarını ve hak ettiklerini korumayı sağlar. Muş masallarında adalet kök değeri ortalarda bir yerde yer bulmuştur. Efsane metinlerinde bu değere rastlanmamıştır. Toplamda 13 adet örnek saptanmıştır. Masallarda yer alan adalet kök değerine ait bazı örnekler şöyledir:

"İlan: "imkani yoh, seni ısıracagım" diyor.

Adam baher çara yoh der:

"O zaman-karşımıza ne çıharsa kim çıharsa- üç kişiden soralım. Onler aramızi bulsın." ilan:

"Temam" der."(M15, Yllanla Adam, s.160)

"İhtiyar da olayı kavramış ve Ahmed’in suçsuz, kendi karısının suçlu olduğunu anlamış." (MA12, Fakir Ahmet, s.108)

\begin{tabular}{r|l} 
Adres & $\begin{array}{l}\text { Address } \\
\text { RumeliDE Dil ve Edebiyat Araştırmaları Dergisi }\end{array}$ \\
RumeliDE Journal of Language and Literature Studies \\
Osmanağa Mahallesi, Mürver Çiçeği Sokak, No:14/8 & Osmanağa Mahallesi, Mürver Çiçeği Sokak, No:14/8 \\
Kadıköy - İSTANBUL / TÜRKIYE 34714 & Kadı̈öy - ISTANBUL / TURKEY 34714 \\
e-posta: editor@rumelide.com & $\begin{array}{l}\text { e-mail: editor@rumelide.com, } \\
\text { phone: +90 505 7958124, +90 } 216773 \text { o } 616\end{array}$
\end{tabular}




\section{Öz denetim}

Öz denetim "kişinin kendisi ve dünya arasında daha iyi, daha ideal bir uyuma sahip olması için kendini değiştirme ve uyarlama kapasitesi" (Duyan, Gülden ve Gelbal, 2012: 19) olarak ifade edilmektedir. Genellikle temizliğe önem verme ve yaptığı bir yanlıştan dönüp özür dileme şeklinde örnekler vardır. Muş masallarında öz denetim kök değerine ait 7 adet örnek bulunmuştur. Efsane metinlerinde bu değere örnek bulunamamıştır. Masallardaki örneklerden iki tanesi şunlardır:

"İlk nöbeti küçük kardeş Ali tutmiş. Çıhmiş damın üstünde sahlanmiş. Ahşama keder evın içini gözlemiş. Ahşama dogri bahmiş ki dolabın arhasından dünyalar güzeli, peri misali bir kız çıhti. Kız etrafi temizlemiş. Daha sonra da abilerıne yemek hazırlemiş.”(M42, Çoban Kızı, s.212)

“Padişah onlardan özür diler.” (MA15, Ömer’in Kaderi, s.114)

\section{Sayg1}

Saygı, iletişim kurulan kişinin üstün özelliklerinin kabul edildiğini anlatan bir kavramdır. Saygı kök değeri Muş masallarında az rastlanan bir değerdir. Sadece 3 yerde tespit edilmiştir. Efsane metinlerinde bu değere örnek bulunamamıştır. Masallarda yer alan saygı kök değerine ait bir örnek şu şekildedir:

"Kambur bu durum karsısında hiçbir rahatsızlık duymaz. Hiç heyecana kapılmaz. O da herkes gibi tahtın üzerinde duran şahsın yanına yaklaşır ve kalabalı̆̆a karışır. Kambur da bir kenarda hürmetle ellerini önünde bağlamış tahtın üzerinde duran adamın karşısında durur.” (M51, Kambur, s.115)

\section{Vatanseverlik}

Vatanseverlik, milli konularda yani vatan, millet, tarih ve devletle ilgili konularda hassas davranma ve düşünme şeklinde tanımlanabilir. Vatanseverlik, masal ve efsanelerin doğası gereği Muş masallarında ve efsanelerinde en az yer alan kök değerdir. Bu metinlerde sadece 2 kere bu değere yer verilmiştir. Onlar da tarihi şahsiyetler etrafında oluşan iki efsanede karşımıza çıkar. Örnekler şunlardır:

"Malazgirt ilçesinde her yıl 26 Ağustos tarihinde olağanüstü bir sıcaklı hasıl olur. 13.oo-14.oo saatleri arası Ahlat tarafindan bir firtına kopar ve tozu toprağa katar. Yaklaşık 4O-45 dakika süren bu tabiat olayı her yıl bu tarihte ve saatte tekrar eder durur. Halk arasındaki inanışa göre her yll bu tarih ve saatte Alp Arslan ve ordusu Bizans ordusunun üzerine aktn etmektedirler. Yaşanan bu doğa olayı halk arasında bu şekilde anlamlandırılmıştır.” (E64, Alparslan'ın Ordusu, s.92)

"Iran seferi surasında Sultan Murat'ın hazinesi boşalır. Durum askeri doyuramayacak hale gelir. Sultan Murat, bu bölgenin zenginlerinden birinden borç almak ister. Fakat adam, borç vermek istemez. Günlerden bir gün yaşh bir kadın Sultan Murat'ın yanına gelir. Sultan Murat’’n halini gören yaşl kadın şöyle bir öneride bulunur:

"iki at kesilsin. Etinden askerler yesin, istifade etsin. Atlarm derisi ise askerler tarafindan tabaklanıp parçalara ayrlsın, padişah mührüyle bunlar para haline getirilsin.”

Kadının dedikleri Sultan Murat'ın hoşuna gider ve Sultan, kadının söylediklerinin hemen uygulanmasinı emreder.

Yaşlı kadının önerisi işe yarayınca Sultan Murat, ekonomik sıkıntıdan kurtulur ve İran fethedilir." (E66, Sultan Murat Yolu, s.93)

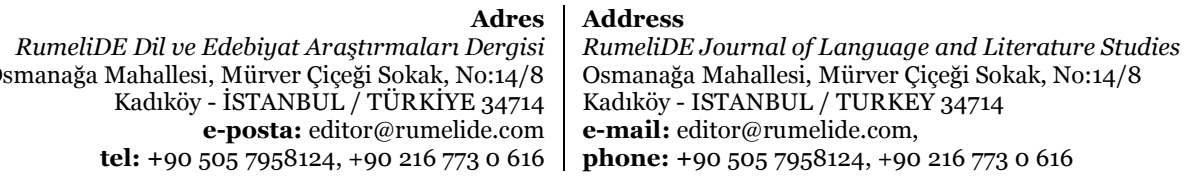

RumeliDE Dil ve Edebiyat Araşttrmaları Dergisi -posta: editor@rumelide.com tel: +90 $5057958124,+902167730616$
Address

Osmana

phone: +90 505 7958124, +90 2167730616 


\section{Sorumluluk}

Sorumluluk, "bireyin toplumda etkin işlev görebilmesi, yaşının gerektirdiği öğrenme ve eğitim etkinliklerini gerçekleştirebilmesi için oldukça önemli bir kavram" (İkiz, Totan ve Karaca, 2013: 24) olarak tanımlanabilir. Muş masallarında sorumluluk kök değeri için çok az örnek vardır. Sadece 2 örnek saptanmıştır. Onlar da şu örneklerdir:

"Varmiş, yohmiş. Bi kadının üç ogli varmiş. Bigün anneleri onlara der ki:

“Ogıllarım sız büyüdünız. Bundan böle kendı başınızın çaresıne sız bahın.” der. Bu uç kardeş de kendı aralarınde anlaşırler: Herbiri çarşinın bi terefini tutar.” (M40, Üç Kardeş, s.207)

"Bulanık'ta bir süre kaymakamlk yaptıktan sonra tövbe edip tarikata girer. Burada çilehanede kurk gün çile çeker. Günde bir hurma ile beslenir. Norşin'de yaşayan şeyhten icazet alır.” (E88, Seyyid Şeyh Tahir, s.103)

\section{Diğer değerler}

Muş yöresine ait masal ve efsanelerde tespit edilen ve kök değer olmayan diğer değerler, bu değerlerin frekansları ve yer aldıkları masallar Tablo 2'de verilmiştir.

Tablo 2. Muş yöresine ait masal ve efsanelerde tespit edilen kök değerlerin dişinda kalan diğer değerler, değerlerin frekanslari ve yer aldiklari masal ve efsaneler

\begin{tabular}{|c|c|c|c|c|}
\hline Tema 2 & $\begin{array}{l}\text { Sira } \\
\text { No }\end{array}$ & Değerler & (f) & $\begin{array}{l}\text { Değerlerin Yer Aldığı Masallar ve } \\
\text { Efsaneler }\end{array}$ \\
\hline \multirow{6}{*}{ Diğer } & 1 & Dini değerlere duyarlılık & 73 & $\begin{array}{l}\text { M1, M2, M19(2), M35, M37(3), M38(3), M39, } \\
\text { M40(2), M41, M42, M43, M47(3), M49, } \\
\text { M50(4), M52, E2, E4, E8, E9, E10, E13, E14, } \\
\text { E15, E17, E18, E20, E21, E23, E24(3), E30, } \\
\text { E32, E38, E42, E51, E57, E60, E65, E70, E71, } \\
\text { E74, E75, E82, E84, E92, E95, E98, E99, E101, } \\
\text { MA4, MA8, MA12(3), MA15, MA45, MA54, } \\
\text { MA57, MA58, MA67, MA69. }\end{array}$ \\
\hline & 2 & Estetik & 56 & $\begin{array}{l}\text { M2, M12, M42(3), M43, M44(4), M49(3), M50, } \\
\text { M51(2), M52, M54(6), E30, E48, E61, E66, } \\
\text { E100(2), MA1, MA11, MA12, MA13, MA14, } \\
\text { MA17, MA19, MA22, MA23, MA25, MA28, } \\
\text { MA29, MA35, MA43(2), MA44, MA45, MA46, } \\
\text { MA49, MA52, MA59, MA62, MA63, MA68, } \\
\text { MA69, MA71, MA72. }\end{array}$ \\
\hline & 3 & Azimli olma & 30 & $\begin{array}{l}\text { M16, M20(2), M32(2), M37, M43, M45, M47, } \\
\text { M48, E15, E21, E25, E57(2), E58(2), E60, MA8, } \\
\text { MA10, MA11, MA12, MA22, MA24, MA25, } \\
\text { MA41, MA54, MA64, MA70, MA72. }\end{array}$ \\
\hline & 4 & İyilik etme & 30 & $\begin{array}{l}\text { M15, M39, M42, M43, M45(4), M46, M49, } \\
\text { M50, M51(3), M54(3), E80, E82, MA21(2), } \\
\text { MA25, MA31, MA32, MA41, MA49, MA50(3), } \\
\text { MA60. }\end{array}$ \\
\hline & 5 & Çalışkanlık & 20 & $\begin{array}{l}\text { M30, M38, M39, M41, M45, M49, M51, M53, } \\
\text { M54, E1, E39, MA1, MA8, MA17(2), MA34, } \\
\text { MA37, MA54(2), MA61. }\end{array}$ \\
\hline & 6 & $\begin{array}{l}\text { Aile birliğine/bağlarına önem } \\
\text { verme }\end{array}$ & 19 & $\begin{array}{l}\text { M31, M38, M41, M42, M45, M50(2), M54, } \\
\text { MA3, MA4, MA8, MA17, MA18, MA30, } \\
\text { MA31(2), MA56, MA58, MA59, MA72. }\end{array}$ \\
\hline & $\begin{array}{r}\text { Rum } \\
\text { Osman } \\
\end{array}$ & $\begin{array}{r}\text { Adres } \\
\text { DE Dil ve Edebiyat Araşttrmalar Dergisi } \\
\text { Mahallesi, Mürver Çiçeği Sokak, No:14/8 } \\
\text { Kadıköy - İSTANBUL / TÜRKIYE } 34714 \\
\text { e-posta: editor@rumelide.com } \\
\text { tel: +90 505 7958124, +90 } 2167730616\end{array}$ & \multicolumn{2}{|c|}{$\begin{array}{l}\text { Address } \\
\text { RumeliDE Journal of Language and Literature Studies } \\
\text { Osmanağa Mahallesi, Mürver Çiçeği Sokak, No:14/8 } \\
\text { Kadıköy - ISTANBUL / TURKEY } 34714 \\
\text { e-mail: editor@rumelide.com, } \\
\text { phone: +90 505 7958124, +90 } 216773 \text { o } 616\end{array}$} \\
\hline
\end{tabular}




\begin{tabular}{|c|c|c|c|c|}
\hline \multirow[t]{24}{*}{ Değerler } & 7 & Cömertlik/cömert olma & 17 & $\begin{array}{l}\text { M13, M19, M30, M38(3), M45, M54, E25, E30, } \\
\text { E67, MA29, MA38, MA48, MA50, MA51, } \\
\text { MA71. }\end{array}$ \\
\hline & 8 & Merhametli olma & 16 & $\begin{array}{l}\text { M15, M27, M36, M39, M41(2), M42, M43, } \\
\text { M46, M49, M54, MA12, MA14, MA16, MA37, } \\
\text { MA43. }\end{array}$ \\
\hline & 9 & Geleneksellik & 16 & $\begin{array}{l}\text { M42, M43, M44(2), M50, M54, E26, E29, } \\
\text { E100, MA11, MA12, MA19, MA31, MA43, } \\
\text { MA52, MA72. }\end{array}$ \\
\hline & 10 & Nezaket/kibarlık & 14 & $\begin{array}{l}\text { M29, M37, M44, M45(2), M47, M53, M54(3), } \\
\text { MA15, MA22, MA27, MA66. }\end{array}$ \\
\hline & 11 & Cesaret/cesur olma & 14 & $\begin{array}{l}\text { M20, M42, M47, M54, E65, MA16(2), MA19, } \\
\text { MA30, MA46, MA52, MA56, MA62(2), MA69. }\end{array}$ \\
\hline & 12 & Kahramanlık & 12 & $\begin{array}{l}\text { M43(2), M46, M47, E31, E50, E58, E64, E65, } \\
\text { E85, MA23, MA63. }\end{array}$ \\
\hline & 13 & Uyumlu olma/davranma & 9 & M21, M51(2), E61(2), E81, MA3, MA54, MA64. \\
\hline & 14 & Misafirperver olma & 7 & M27, M45, MA15, MA22, MA31, MA51, MA54. \\
\hline & 15 & Güven duyma & 7 & M3, M7, M37, M39, E25, MA2, MA21. \\
\hline & 16 & Teslimiyet & 7 & M1, E24, E61, E82, E99, MA15, MA57. \\
\hline & 17 & Paylaşımcılık & 7 & M7, M8, M19, M33, M36, M43, M55. \\
\hline & 18 & Sağllk & 7 & M43, M51, E70, E92, MA25, MA53, MA55. \\
\hline & 19 & Affetme/bağışlama & 4 & M44, MA10, MA39, MA52. \\
\hline & 20 & İleri görüşlülük & 4 & M20, M21, M29, MA62. \\
\hline & 21 & Temizlik/temiz olma & 3 & M42, E18, MA31. \\
\hline & 22 & Dayanışma & 2 & M14, MA9. \\
\hline & 23 & Alçak gönüllü olma & 2 & M54, MA71. \\
\hline & 24 & Ümitvar olma & 2 & E15, MA43. \\
\hline & 25 & Fedakârlık & 2 & MA64, MA67. \\
\hline & 26 & Samimiyet /içtenlik & 1 & MA24. \\
\hline & 27 & Bilme/öğrenme isteği & 1 & MA10. \\
\hline & 28 & Sözünde durma & 1 & E30. \\
\hline & 29 & Kanaatkârlık/tokgözlülük & 1 & E88. \\
\hline & 30 & Koruma-kollama & 1 & MA52. \\
\hline
\end{tabular}

Tablo 2 incelendiğinde Muş yöresi masal ve efsanelerinde kök değerlerin dışında kalan 30 farklı diğer değer tespit edilmiştir. Bu durum Muş masallarının ve efsanelerinin diğer değerler bağlamında da zengin olduğunu göstermektedir.

Tablo 2 ayrıntılı olarak ele alındığında Muş yöresi masal ve efsanelerinde kök değerlerin dışında kalan diğer değerde 385 örnek değer tespit edilmiştir. Kök değerlerin toplam sayısı olan 164 ile topladığımızda tespit edilen değer sayısı 549 olmaktadır. Bunlardan en fazla dini değerlere duyarlılık, 73 değer ile yüzde 20'ye yakın sayısıyla dikkati çekmektedir. Bu değeri; estetik (56), azimli olma (30), iyilik etme (30), çalışkanlık (20), aile birliğine/bağlarına önem verme (19), cömertlik/cömert olma (17), geleneksellik (16), cesaret/cesur olma (14), nezaket/kibarlık (14) gibi değerler takip etmektedir.

RumeliDE Dil ve Edebiyat Araştırmaları Dergisi Osmanağa Mahallesi, Mürver Çiçeği Sokak, No:14/8 Kadıköy - ÍSTANBUL / TÜRKIYE 34714 e-posta: editor@rumelide.com tel: +90 $5057958124,+902167730616$
Address

RumeliDE Journal of Language and Literature Studies

Osmanağa Mahallesi, Mürver Çiçeği Sokak, No:14/8

Kadıköy - ISTANBUL / TURKEY 34714

e-mail: editor@rumelide.com,

phone: +90 $5057958124,+902167730616$ 
Aşağıda kök değerlerin dışında kalan bazı diğer değerlerin masallarda nasıl yer aldığına ilişkin örnekler verilmiştir:

\title{
Dinî değerlere duyarlılık
}

İnanç temelli değerlere duyarlılık, bireylerin kişisel yaşamlarında, sosyal hayatlarında ve diğer insanlarla iletişiminde her zaman önemli olagelmiştir. Bu özelliklerinden dolayı toplamda en çok örnek bu konuda tespit edilmiştir. Muş yöresi masal ve efsanelerinde dinî değerlere duyarlılık değerine yönelik 73 örneğin olduğu saptanmıştır. Masal ve efsanelerde yer alan dinî değerlere duyarlılık değerine ait birkaç örnek şu şekildedir:

“Arkadaşleri onı bu güzel saçlerıni görnnce heyr etetmisler. Hem de çoh kızkanmişler; ama o keder güzel saçleri varmiş ki herkez ona altun saçli kız demah zorınde kalmiş. Bu durtm, kızın çoh hoşıne gitmiş. Allah'a şükretmiş. O günden sonra da onın adi 'altun saçli kız' olarah kalmiş.” (M49, Altın Saçlı Kı, s.230)

"Üçüncü nasihat: Sabah ezanın duyduğun anda nerede olursan olsun abdestini alıp namazını kılacaksin.”(MA12, Fakir Ahmet, s.106)

“Hep birlikte Allah'a şöyle dua ederler:

"Allah’im bize bir çeşme göster, su içelim. Bu nimetin için sana bir kurban verelim." (E8, Gelin Çeşmesi, s.68)

\section{Estetik}

Estetik; masal ve efsanelerde daha çok edebi ve sanatsal anlatım şeklinde karşımıza çıkan bir kavramdır. Arıcı (2016: 1021) "İnsanlarda hoş duygular ve heyecan oluşturan şeylerin inceleme ve değerlendirilmesi estetik ile ilgilidir. Estetik bir anlamda güzel olanın araştırılmasıdır.” ifadeleriyle estetik kavramını tanımlamaktadır. Muş yöresine ait masal ve efsanelerde estetik değerine çok fazla yer verilmiştir (56). Ayrıca bu değer, metinlerdeki kahramanların fiziksel tasvirlerinde ve masal başlarında söylenen tekerlemelerde de kendine yer bulmaktadır. Masal ve efsanelerde yer alan estetik değerine ait bazı örnekler şöyledir:

"Der ki:

\author{
Hey vitvit eden guş \\ Hesabun oldi yalniş \\ Özin evini yıhtun \\ Beni de evsiz burahtın.” (M2, Tüccar Pire, s.144)
}

“Tasa kuşu: 'Tasa dediğin öyle olmaz, böyle olur: Geçti ayva, geçti nar. İster taş ye ister hardal.' Demiş." (MA43, Tasa Kuşu, s.171)

"Süphan Dağı’nın zirvesinde bulunan Gola Mem u Zine, bu iki sevgilinin sonsuz aşklarının bir sembolüdür. Rivayete göre Mem ile Zin, bu gölden birlikte su içmişlerdir. Bu yüzden bu göl asla kurumaz ve sonsuza kadar var olmaya devam edecekmiş." (E48, Mem ve Zin Gölü, s.85)

"Bunu duyan Sultan köprüden geçmeyi reddeder ve şu dörtlükle cevap verir:

Geçme namert köprüsünden,

Koy sel götürsün seni.

Yatma tilki gölgesinde,

Koy aslan yesin seni." (E66, Sultan Murat Yolu, s.93)

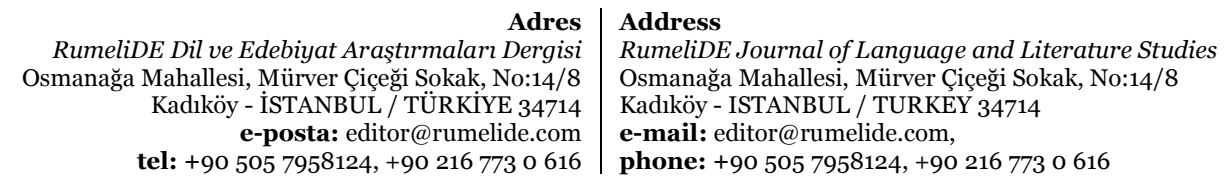




\section{Azimli olma}

Muş masal ve efsanelerinde yer alan önemli değerlerden biri de azimli olma değeridir. Azim ile bir işi yapma, kararıı bir şekilde olayların üstüne gitme ve zorluklar karşısında yılmama gibi durumlar masal ve efsanelerde çok kullanılmıştır. Muş yöresi masal ve efsanelerinde azimli olma değerine yönelik 30 örnek tespit edilmiştir. Masal ve efsanelerde yer alan azimli olma değerine ait bazı örnekler şu şekildedir:

"Sira Mirza Mihemede gelmis, getmis gece agaci beklemis. Uyhusi gelınce barmagini kesmiş, tuz koymiş uyhusi gelmesin diye. Gece yarisi olnce, bahmiş birisi gelmiş almayi çalmaga. Mirza Mihemed oni görmiş kovalamiş. Getmiş bi migaraye girmiş. Mirza Mihemed sabah eve gelmiş, kerdeşlerıne meseleyi anlatmiş. Getmiş̧ler mıgaranın başına, sirit de getırmişler. İlkin büyük kerdeş içeri girmiş, hemen bagirmiş demiş: "Eman meni çekn yuhari!” O çıhmiş, ortadaki girmiş magereye. O da eyni öburi gibi bagırmiş, demiş: "Meni çekın." O da çıhmiş. Stra gelmiş Mirza Mihemede. Demiş: "Ben getsem, ne keder desem meni çekın, siz çekmeyın."Brrahmişler, mıgerenın dibıne getmiş. Bagırmiş, çagırmiş ama oni çıharmamişler." (M21, Dev Kız, s.172)

“Ağabeylerini bulmaya ne pahasina olursa olsun onlar kurtarmaya karar vermiş.” (MA24, Yedi Kargalar, s.137)

"Komşu eve geri döner. Kadın, yedi defa bu eve çeşitli bahanelerle et yemek umuduyla gider gelir. Fakat ev sahibi et vermez." (E15, Ayının Menşei, s.71)

\section{Cömertlik/cömert olma}

Cömertlik, "sahip olunan imkân ve varlıkları ahlaki ölçüler içinde başkaları ile paylaşmak" biçiminde tanımlanabilir (Şener, 2013: 2513). Metinlerde bu değere, üçü efsanelerden olmak üzere 17 örnek saptanmıştır. Daha çok karşıdaki muhtaç insanlara yardım etmek şeklinde görülür. Masal ve efsanelerde yer alan cömertlik/cömert olma değerine ait bazı örnekler şöyledir:

"Bir varmiş, bir yohmiş. Zengin ve iyi kalbli bi adam varmiş. Bu adam Allah için en heyrrli ibabeti arastırtrmiş. Din adamlerının yanıne gitmiş, onlere sormiş:

“Allah için en hayırli olan, mükafatı en fazla olan nedır?” Onlar da malıni Allah yolnde tesaddük etmesıni, fekir-fukeraya yardımci olmasıni söylemişler. Bu zengin adam da tüm malıni mülkini fekir ve fukeraya vermiş. Elınde sadece yatagi ve ati kalmiş.”(M38, Bezirgan, s.202)

"Geminin içindeki altınları karaya varınca hepsin, kurtuldukları takdirde bağış yapacağını söylüyorlar, sonunda karaya varı altınları dağıtıyorlar.” (MA38, Kayı Hazine Avcıları, s.163)

"Cin padişahının kızı, bütün altınlarını bu talebeye verir ve onunla nişanlanır." (E3o, Talebe ile Cin, s.77)

\section{Geleneksellik}

$\mathrm{Bu}$ değer, masal ve efsanelerde kültürel ve yöresel unsurlar bağlamında yer almıştır. Geleneksellik, daha çok dügün, yemek daveti vb. şekillerde karşımıza çıkmaktadır. Muş yöresi masal ve efsanelerinde geleneksellik değeri ortalarda yer bulmuştur (16). Masal ve efsanelerde yer alan geleneksellik değerine ait bazı örnekler şu şekildedir:

"Sabahleyin büyük ve ortanca kızları evlendiriyor. Düğünler senlikler yapılyor. Yiyiliyor, içiliyor. Büyük ve ortanca kız muratlarına eriyorlar.”(M52, Üç Bacı, s.129)

“İyileştikten sonra Çil Osman ile Nurcemal’in 40 gün 40 gece düğünleri yapılır Herkes eğlenir." (MA11, Çil Osman, s.104)

"Kedi, davul ve zurna eşliğinde halay çeken birilerinin yanına varır ve bir gence dönüşerek halaya katılır."(E26, Devçizoro, s.76)

\begin{tabular}{r|l} 
Adres & Address \\
RumeliDE Dil ve Edebiyat Araştırmaları Dergisi & RumeliDE Journal of Language and Literature Studies \\
Osmanağa Mahallesi, Mürver Çiçeği Sokkak, No:14/8 & Osmanağa Mahallesi, Mürver Çiçeği Sokak, No:14/8 \\
Kadıköy - İSTANBUL / TÜRKIYY 34714 & Kadıköy - ISTANBUL / TURKEY 34714 \\
e-posta: editor@rumelide.com & e-mail: editor@rumelide.com, \\
phone: +90 505 7958124, +90 2167730616
\end{tabular}




\section{Cesaret/cesur olma}

Cesaret veya cesur olma hâli, "Güç veya tehlikeli bir işe girişirken kişinin kendinde bulduğu güven.” (TDK Türkçe Sözlük, 2011: 455) olarak tanımlanmaktadır. Muş masal ve efsanelerinde de cesur olma değerine ortalama bir yer verilmiştir (14). Özellikle insanların daha güçlü insanlara veya dev, cin gibi diğer canlılara karşı korkusuzca hareket etmeleri şeklinde görülür. Masal ve efsanelerde yer alan cesaret/cesur olma değerine ait bazı örnekler aşağıda verilmiştir:

"Küçük kız gene zindancıya yalvarıyor. Git padişaha haber götür. Ben artık cezamı çektim. Ya beni azat etsin, veyahut da idam ettirsin.” (M52, Üç Bac1, s.131)

"Keloğlan lakaplı kız:

-Ben devi öldürmeye gidiyorum demiş.” (MA19, Kız Evladın Hikayesi, s.125)

“Cibranlı Halil, Hinıs'ın Hamzabey köyünde çetesi ile birlikte dinlenirken Rus askerleri tarafindan etrafi sarılır. Mart ayının soğuk günlerinden biridir ve Halit Bey dişında kimsenin atı yoktur. Halit Bey, adamlarına "Ben düşman askerlerini yartp atımla karşıya geçtiğim sırada düşmana ateş açacağım. Siz de bu arada canınız kurtarın” der. Halit Bey, atıyla düşman askerini yarıp karşıya geçtiği sırada çete üyeleri de onun açtı̆̆ ateş sayesinde düşman askerlerinden kurtulurlar.” (E65, Cibranlı Halil Bey, s.92)

\section{Nezaket/kibarlık}

Nezaket; bireyin karşıdaki kişi veya kişileri kırmadan, onları küçük düşürmeden sert bir dil kullanmadan bağlantı kurmasıdır. Bu durum aslında kişinin kendisine de saygısı demektir. Muş masallarında bu değere 14 örnek tespit edilmiştir. Efsanelerde bu değere örnek bulunamamıştır. Masallarda yer alan nezaket/kibarlık değerine ait bazı örnekler şu şekildedir:

"Padişah cemeetiyle gelmiş. Kız çıhmiş meydane, demiş benım kelentm:

"2o koyin, 30 koç; 50 at, 70 yehte; 90 feraset, 100 akıl..."

Padişah heyetune diyor:

"Kahın gidah, bu iş olmaz."

Heyeti sormiş:

"Neden olmaz padişahım?"

Padişah demiş:

"Kız bana diyor ben yirmi yaşımdeyim, bana otı yaşınde bir delikanli lazım. Erkek elli yaşıne girende at gibi oltr. Yetmis yaşıne girende yehte gibi olır. Kız diyor insan ömri doksan oldi mi feraseti gidiyor. Yüz oldi mi akli de gidiyor. Hemen kalhın gidah.” (M29, Vezir ile Köylü Kızl, S.184)

"Padişah:- Misafir kabul eder misiniz?

Kadın:- Lütfen içeri girin. der.” (MA15, Ömer’in Kaderi, s.114)

\section{Sonuç, tartışma ve öneriler}

Muş iline ait masal ve efsanelerin değerler eğitimi açısından incelendiği bu çalışmada çeşitli sonuçlara ulaşılmıştır. Çalışma kapsamında masal ve efsanelerde kök değerlerin tamamına ait örneklerin olduğu saptanmıştır. Bunun yanı sıra kök değerlerin dışında kalan ve diğer değerler olarak ifade edilen 30 farklı değere de ulaşılmıştır. Çalışmada ulaşılan sonuçlar alan yazında yapılmış benzer çalışmalarla tartışlmıştır.

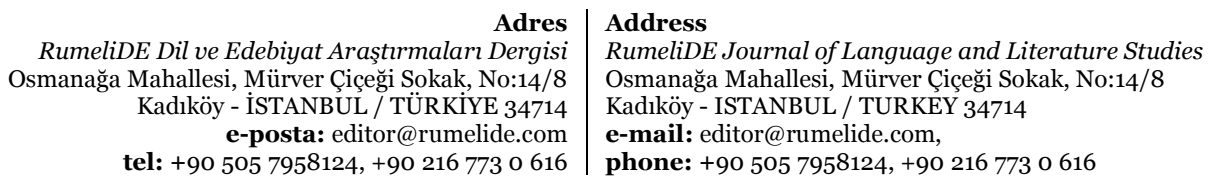


Çalışma kapsamındaki toplam 127 masal ve 101 efsanede 10 kök değerin tamamına ait örnekler mevcuttur. Bunun yanı sıra kök değerlerin dışında kalan farklı 30 değere de ulaşılmıştır. Masal ve efsanelerin içinde toplamda 549 değer tespit edilmiş ve bu durum dikkate alındığında metinlerin değer eğitimi açısından zengin örnekler içerdiği söylenebilir.

Çalışmada kök değerler bakımından en fazla yardımseverlik (53), sevgi (39), dürüstlük (16), sabır (15), dostluk (14), adalet (13) ve öz denetim (7) kök değerlerine yer verildiği saptanmıştır. Bunun yanı sıra saygı (3) sorumluluk (2) ve vatanseverlik (2) değerleri ise masal ve efsanelerde en az yer alan kök değerlerdir. Masal ve efsanelerde kahramanların yardımsever olmaları önemli bir özelliktir. Yardımseverlik, toplum içindeki bireylerin hayatlarını devam ettirmesi için birbirlerinin ihtiyaçlarını gidermesi olarak tanımlanabilir. Genellikle karşılıklı menfaat gereği olan bu durum bazen çıkar gözetmeksizin yapılır. Her meslek sahibi; toplum hayatının devam etmesi için bir şeyler üretir, karşılı̆̆ında ücretini alır. Fırıncı, tamircinin ekmeğini yapar; tamirci, fırıncının makinesini tamir eder; öğretmen her ikisinin çocuğunu eğitir. Böylece toplumda birbirlerinin ihtiyacı olan şeyleri yerine getirmiş olurlar. Ayrıca masal ve efsanelerde insan dışı varlıklara yardım edilmesi veya bu varlıkların insana yardım etmesi gibi durumlar da bulunmaktadır.

Muş yöresine ait masal ve efsanelerde kök değerlerin dışında kalan 30 farklı diğer değer olduğu tespit edilmiştir. Bu masal ve efsanelerde kök değerlerin dışında kalan 'diğer' değerlerde en fazla işlenen değer ise dini değerlere duyarlılıktır. Dini değerlere duyarlılık, bireylerin yaşamının her yerinde önemlidir. Kutsal dinler veya diğer inanç sistemleri insanların olumlu davranışlar içinde olması için kurallar koyan ve bu kurallar aracılı̆̆ıyla insanları iyiye ve doğruya sevk eden kurumlardır. Bu kurumlar, toplum ve birey hayatı için büyük önem arz etmektedirler. Bu özelliklerinden dolayı çalışmada en fazla bu değere yönelik örnekler bulunmuştur. Muş yöresi masal ve efsanelerinde dinî değerlere duyarlılık değerine yönelik 73 örneğin olduğu saptanmıştır. Bu rakam diğer değerlerin yaklaşık yüzde 20'sine tekabül eder. Kök değerlerle birlikte toplam alındığında ise yüzde 13 'ten fazla bir rakam olmaktadır. Bu durum, genel olarak toplumumuzda özelde ise bölge ve Muş insanında dine karşı olumlu ve yüksek bir tavrın bulunduğunu göstermektedir. Ayrıca bölgede yaşayan insanların çoğunluğunun ve anlatan kişilerin dini değerlere duyarlı insanlar olduğunun bir göstergesi olarak yorumlanabilir. Bazı dini efsanelerin alevi kültürünün geleneklerini yansıttığı da dikkate alınması gereken bir bilgidir. Ortak değerlerin bulunduğunun ispatı olan bu durum dinin insanlar üzerindeki birleştiriciliğini gösterir. Masal ve efsanelerde dini değerlerin hayatın her alanında örneklerini bulmak mümkündür. Zaten bazı efsaneler dini özellikteki kişilerin hayatını ele alan menkıbe denilen efsanelerdir. Türk Dünyası Masallarmın Değerler Ĕ̆itiminde Kullanılabilirliği isimli yüksek lisans çalışmasında Özcan (2017) dini değerlere duyarlılık değerinin bu masal ve efsanelerde önemli bir yer edindiğini saptamıştır.

Kök değerler bakımından sadece masal örneklerine bakıldığında 48 örnek ile yardımseverlik birinci sırada yer alır. Yardımseverlik; sevgi, iyilik gibi bazı değerleri içinde barındıran bir kök değerdir. Yardımsever kişi, diğer varlıkları seven ve onlara iyilik yapmayı isteyen kişidir. Bu değeri dürüstlük (14), sevgi (13), adalet (13), dostluk (12) ve sabır (11) takip eder. Kök değerlerden vatanseverlik değerine masallarda örnek saptanmamıştır. Muş yöresine ait masallarda kök değerlerde en az sorumluluk (1), saygı (3) ve öz denetim (7) değerlerine ulaşılmıştır. Alan yazında masallarla ilgili yapılan çalışmalarda genelde sevgi değerinin ilk sırada yer aldığı tespit edilmiştir. Alabay Yolcu (2019), Kılıç ve Yılmaz (2018), Bulut (2021) ve Özbaşı (2020) çalışmalarında en fazla sevgi değerinin yer aldığını saptamışlardır. Bu çalışmada ise sevgi değeri, toplamda ikinci sırada ve sadece masallara bakıldığında 3. sırada yer alır. Bu çalışmada ilk sırada yer alan yardımseverlik, Akkaya (2017) ve Kılcan

\begin{tabular}{r|l} 
Adres & Address \\
RumeliDE Dil ve Edebiyat Arastrmalar Dergisi & RumeliDE
\end{tabular}

DE Journal of Language and Literature Studies Osmanağa Mahallesi, Mürver Çiçeği Sokak, No:14/8 Osmanağa Mahallesi, Mürver Çiçeği Sokak, No:14/8 Kadıköy - İSTANBUL / TÜRKIYE 34714 Kadıköy - ISTANBUL / TURKEY 34714 e-posta: editor@rumelide.com e-mail: editor@rumelide.com,

tel: +90 505 7958124, +90 2167730616 phone: +90 505 7958124, +90 2167730616 
(2016)'ın çalışmalarında da ilk sırada yer alır. Özbaşı (2020)'nın çalışmasında 2. sırada; Bulut (2021)'un, Arslan ve Çelik (2016)'in çalışmalarında ise 3. sırada yer alması çalışmanın bu bulgusuyla örtüşmektedir.

Kök değerler bakımından sadece efsane örnekleri incelendiğinde 13 değer ile sevgi birinci sırada yer alır. Bu değeri yardımlaşma (5), sabır (2) ve vatanseverlik (2) takip eder. Kök değerlerden adalet, öz denetim ve saygı değerlerine ait örnek efsanelerde saptanmamıştır. Efsaneler, doğası gereği masallardan daha az sayıda değer içermektedir. Bu çalışmada da kök değer bakımından efsanelerde toplam 25 kök değer örneğine ulaşılmıştır. Bu sayı masallarla karşılaştırıldığında neredeyse altıda bire yakındır. Alan yazında efsanelerde sadece kök değerlerin ele alındı̆̆ı hiç çalışma bulunmamıştır. Ayrıca efsanelerde değerlerin ele alındığı çalışma sayısı ise sınırlı sayıdadır. Çiftçi ve Sayır (2019)'ın çalışmasında bir efsane ele alınmış ve o efsanede bulunan eğitici değerler irdelenmiştir. İlgili çalışmada kök değerlerden sadece sevgi değerinin bulgusu örneklendirilmiştir.

Güven (2014) Türk Efsanelerinin Değerler Eğitimi Bakımından İncelenmesi isimli çalışmasını 20 değer üzerinden incelemiştir. Ortak olan değerlere bakıldığı zaman, bu çalışmada olduğu gibi, sevgi değerinin ilk sırada ve yardımseverlik değerinin 3. sırada olması dikkat çekmektedir. Bütün Türk dünyası efsanelerini ele alan ilgili çalışma ile bu çalışmanın sonucunun benzerlik göstermesi bu bağlamda önemlidir. Sevgi ve yardımseverlik değerlerinin benzer şekilde sonuçlanması Türk dünyası insanı ile genelde Anadolu ve özelde Muş insanının sevgiye ve yardımlaşmaya ne kadar önem verdiğini ortaya koymaktadır.

Kök değerler dışındaki diğer değerler bakımından sadece masal örnekleri incelendiğinde estetik değeri (50) birinci sırada yer alır. Estetik değerinin önde çıkmasının sebebi, anlatan kişilerin anlatımında sanatsal bir anlatım tarzını benimsemeleri olduğu söylenebilir. Bu değeri dini değerlere duyarlılık (38), iyilik (28), azimli olma (22), aile bağlarına önem verme (19) ve çalışkanlık (18) takip eder. Kök değerler dışındaki diğer değerler bakımından sadece masal örneklerine bakıldığında sözünde durma ve kanaatkârlık/tokgözlülük değerlerine masallarda örnek saptanmamıştır. Samimiyet/içtenlik, bilme/öğrenme isteği, koruma-kollama ve ümitvar olma değerlerinde sadece birer örnek tespit edilmiştir. Alan yazında yapılan masallarla ilgili çalışmalarda genelde kök değerlerin dışında değerler incelenmemiş veya farklı gruplandırmalar esas alınmıştır. İlgili çalışmalarda iyilik değerinin ilk sırada yer aldığı saptanmıştır. Alabay Yolcu (2019)'nun tezinde evrensel değerler, milli değerler, manevi değerler ve kişisel değerler ana başlıklarını kullanmıştır. Bu başlıklar altında alt başlıklar verilmiş ve buna göre incelenmiştir. Kök değerlerin dışında kalan diğer değerler içinde dini değerlere duyarlılı̆̆ın alt başlığı olan dua etmek başlığı ilk sırada yer almıştır. Kılıç ve Yılmaz (2018)'ın çalışmasında iyilik değeri en fazla tespit edilen değer olmuştur. Bulut (2021), çalışmasında kök değerler dışında kalan diğer değerlerden en fazla merhamet değerini tespit etmiştir.

Efsane metinlerinde kök değerlerin dışında yer alan diğer değerlerde ise en fazla dini değerlere duyarlılık (35) değerine yer verilmiştir. Bu değeri azimli olma (8), estetik (6), kahramanlık (6) ve cömertlik (3) takip eder. Kök değerler dışındaki diğer değerler bakımından sadece efsane örneklerine bakıldığında koruma-kollama, bilme/öğrenme isteği, samimiyet/içtenlik, fedakârlık, alçak gönüllü olma, dayanışma, ileri görüşlülük, affetme/bağışlama, paylaşımcılık, misafirperver olma, cesaret/cesur olma, nezaket/kibarlık, merhametli olma ve aile birliğine/bağlarına önem verme değerlerine efsanelerde örnek saptanmamıştır. Çiftçi ve Sayır (2019)'ın çalışmasında sadakat, kararlılık ve dua etmek gibi bulgular örneklendirilmiştir. Bu çalışmada da dini değerlere bağlllık ve kararlılık değerlerinin ön planda olduğu tespit edilmiştir. Güven (2014)'in çalışmasında ise kök değerlerin

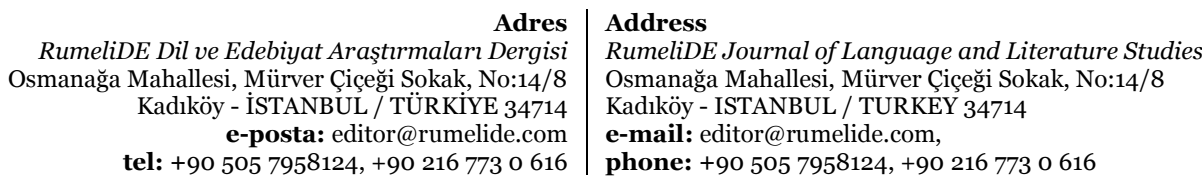


dışında kalan diğer değerler açısından dayanışma, çalışkanlık ve estetik değerleri en fazla saptanan değerlerdendir. İlgili çalışmada çalışkanlık ve estetik değerine fazla sayıda yer verilmesi sonucu da bu çalışma ile benzerlik göstermektedir.

Araştırmada ulaşllan bulgular bağlamında şu öneriler sunulmuştur:

- Bu çalışmada Muş iline ait masal ve efsanelerde yer alan değerler incelenmiştir. Muş iline ait diğer halk edebiyatı ürünlerinin de değerler eğitimi bağlamında incelenmesi ele alınabilir.

- Varto ilçesinde bulunan Alevi Bektaşi kültüre ait ürünler değerler bağlamında incelenebilir.

- Muş iline ait masal ve efsaneler farklı değer sınıflamalarına göre de incelenebilir.

\section{Kaynakça}

Akbaş, O. (2004). Türk Milli Eğitim Sisteminin Duyuşsal Amaçlarmın İlköğretim II. Kademedeki Gerçekleşme Derecesinin Değerlendirilmesi (Yayımlanmamış Doktora tezi). Gazi Üniversitesi Eğitim Bilimleri Enstitüsü, Ankara.

Akkaya, N. (2017). Kıbrıs Türk Masallarında Değerler. Folklor/Edebiyat, 23 (90), 231-244.

Aksu, B. (2010). Muş Çocuk Folkloru. (Yayımlanmamış Yüksek Lisans Tezi), Yüzüncü Yıl Üniversitesi /Sosyal Bilimler Enstitüsü, Van.

Alabay Yolcu, T. (2019). Hasan Lâtif Sarıyüce'nin Anadolu Masallarının Eğitsel Değerler Açısından İncelenmesi, (Yayımlanmamış Yüksek Lisans Tezi), Erzincan Binali Yıldırım Üniversitesi/Sosyal Bilimler Enstitüsü, Erzincan.

Arıcı, A. F. (2016). Estetik Değer Oluşturmada Masalların Rolü: Türk Masalları Örneği. Erzincan Üniversitesi Eğitim Fakültesi Dergisi, (18), 2, 1017-1035.

Arslan, A., \& Çelik, H. (2016). Divan-ı Hikmet’te Türkçe Eğitiminde Kullanılabilecek Değerler. Turkish Studies International Periodical for the Languages, Literature and History of Turkish or Turkic, 11(3), 169-184.

Bulut, K. (2021). Ayla Kutlu'nun Merhaba Sevgi Adlı Çocuk Romanının Değerler Eğitimi ve On Kök Değer Açısından İncelenmesi. Mehmet Akif Ersoy Üniversitesi Eğitim Fakültesi Dergisi, (57), 248-272.

Creswell, J. W. (2005). Educational Research: Planning, Conducting And Evaluating Quantitative And Qualitati And Research. USA: Pearson Prentice Hall.

Çepni, S. (2012). Araştırma ve Proje Çalışmalarına Giriş. Trabzon: Celepler Matbaacllık.

Çiftçi, F.,\& Sayır, M. F. (2019). Efsane Türünün Eğitici Boyutu ve Kızıl Ziyaret Efsanesi’nde Aktarılan İletiler. Çocuk Edebiyat ve Dil Ĕ̈itimi Dergisi, 2(2), 178-196.

Demir, Ş. (2019). Feridun Oral’n Resimli Öykü Kitaplar Üzerine Bir Doküman İncelemesi. (Yayımlanmamış Yüksek Lisans Tezi). Hacettepe Üniversitesi/Eğitim Bilimleri Enstitüsü, Ankara.

Duyan, V., Gülden, Ç. ve Gelbal, S. (2012). Öz-Denetim Ölçeği ÖDÖ: Güvenirlik ve Geçerlik Çalışması. Journal of Society \& Social Work, 23 (1), 25-38.

Ekmekçi, D. N. (2020). Muş Efsaneleri İnceleme Metin. (Yayımlanmamış Yüksek Lisans Tezi), Akdeniz Üniversitesi/Sosyal Bilimler Enstitüsü, Antalya.

Güven, A. Z. (2014). Türk Efsanelerinin Değerler Eğitimi Bakımından İncelenmesi. Mustafa Kemal Üniversitesi Sosyal Bilimler Enstitüsü Dergisi, 11(26), 225-246.

Halstead, J. M.,\& Taylor, M. J. (2000). "Learning and teaching about values: A review of recent research." Cambridge Journal of Education, 30 (2), 169-202.

\begin{tabular}{r|l} 
Adres & Address \\
RumeliDE Dil ve Edebiyat Araşttrmaları Dergisi & RumeliDE Journal of Language and Literature Studies \\
Osmanağa Mahallesi, Mürver Çiçeği Sokak, No:14/8 & Osmanağa Mahallesi, Mürver Çiçeği Sokak, No:14/8 \\
Kadıköy - İSTANBUL / TÜRKIYY 34714 & Kadıköy - ISTANBUL / TURKEY 34714 \\
e-posta: editor@rumelide.com & e-mail: editor@rumelide.com, \\
phone: +90 505 7958124, +90 2167730616
\end{tabular}


Ilıcak, N. G.,\& Başoğlu, N. (2018). Ahmet Ümit’in Masal Kitaplarında Yer Alan Değerlerin Incelenmesi. Karaelmas Eğitim Bilimleri Dergisi, 6(1), 88-100.

İkiz, F. E., Totan, T. ve Karaca, R. (2013). Sorumluluk İnançlarını Arttıran Faktörleri Belirleme Ölçeğinin Uyarlanması. New/Yeni Symposium Journal, 51 (2), 105-115.

Karagöz, B. (2017). Naki Tezel'in Türk Masalları Adlı Kitabının Değerler Açısından Analizi. Ana Dili Eğitimi Dergisi, 5(3), 534-556.

Karasar, N. (2007). Bilimsel Araştırma Yöntemi. Ankara: Nobel Yayınları.

Karatay, H. (2007). Dil Edinimi ve Değer Öğretimi Sürecinde Masalın Önemi ve İşlevi. Türk Eğitim Bilimleri Dergisi, 5(3), 463-477.

Kardaş, C. (2020). Mitoloji Kaynaklı Bir Anlatı. Bulanık/Kop İnsan-Coğrafya-Tarih-Kültür. (Edt. İrşad Sami Yuca). Konya: Çizgi Yayınları.

Kardaş, S. (2020). Bitlis Halk Masallarının Çocuğa Uygunluğu ve Değerler Eğitimine Katkısı Üzerine Bir İnceleme. (Yayımlanmamış Yüksek Lisans Tezi). Van Yüzüncü Yıl Üniversitesi/Eğitim Bilimleri Enstitüsü, Van.

Kasımoğlu, H. (2010). Van Yöresine Ait Türk Halk Masalları. (Yayımlanmamış Doktora Tezi). Gazi Üniversitesi/Sosyal Bilimler Enstitüsü, Ankara.

Kılcan, B. (2016). Ignác Kúnos'un Kırk Dört Türk Peri Masalı Adlı Eserinin Değerler Açısından Incelenmesi. Turkish Journal of Education (TURJE), 5(3),82-94.

Kılıç, B. S., \& Yılmaz, O. (2018). Fakir Baykurt'un Masallarında Değer Eğitimi ve Masalların Türkçe Eğitimine Katkısı. Uluslararası Teke Dergisi, 7(2), 1104-1125.

Köse, A. (2004). Muş İli Malazgirt İlçesinde Anlatılan Masalların Çocuk Eğitimine Katkısı. (Yayımlanmamış Yüksek Lisans Tezi), Selçuk Üniversitesi/Sosyal Bilimler Enstitüsü, Konya.

MEB. (2017). Müfredatta Yenileme ve Değişiklik Çalş̧malarımı Üzerine. Çevrim-içi: http://ttkb. meb.gov.tr/meb_iys_dosyalar/2017_07/18160003_basin_aciklamasi-program.pdf.

Merriam, S. B. (2013). Nitel Araştırma - Desen ve Uygulama İçin Bir Rehber / Qualitative research a guide to design an implementation. (S. Turan, Çev.). Ankara: Nobel Akademik.

Oğuzkan, A. F. (1993). Eğitim Terimleri Sözlüğü (3.Baskı). Ankara: Gül Yayıncllı.

Özbaşı, S. (2020). Türkçe Dersi Öğretim Programındaki Kök Değerler Çerçevesinde Aytül Akal Masallarının İncelenmesi. IBAD Sosyal Bilimler Dergisi, (8), 178-193

Özcan, E. (2017). Türk Dünyası Masallarının Değerler Eğitiminde Kullanılabilirliği. (Yayımlanmamış Yüksek Lisans Tezi) Atatürk Üniversitesi/Eğitim Bilimleri Enstitüsü, Erzurum.

TDK (2011). Türkçe Sözlük. Ankara: Türk Dil Kurumu Yayınları.

Şener, H. (2013). Hayriyye-i Nabi'de Aktarılan Değerler. Turkish Studies, 8(1), 2051-2524.

Yaşaroğlu, C. (2015). İlkokul Programlarında Yer Alan Değerler Üzerine Karşılaştırmalı Bir Inceleme. Route Educational and Social Science Journal, 2(4), 164-174.

Yavuz, M. Ş. (2006). Muş Masalları Üzerine Bir Aaraştırma. (Yayımlanmamış Yüksek Lisans Tezi), Yüzüncü Yıl Üniversitesi/Sosyal Bilimler Enstitüsü, Van.

Yeniasır, M. (2015). Kıbrıs Türk Masallarında Yer Alan Değerlerin İncelenmesi. International Journal of Languages' Education and Teaching, 943-1953.

Yıldırım, A. ve Şimşek, H. (2008). Sosyal Bilimlerde Nitel Araştırma Yöntemleri. Ankara: Seçkin.

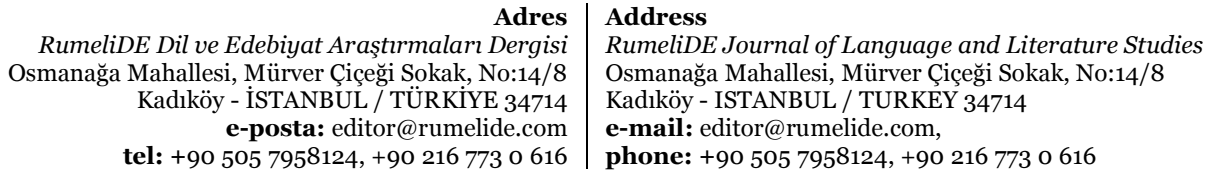

tel: +90 505 7958124, +90 2167730616 
EK 1:

Muş Masalları

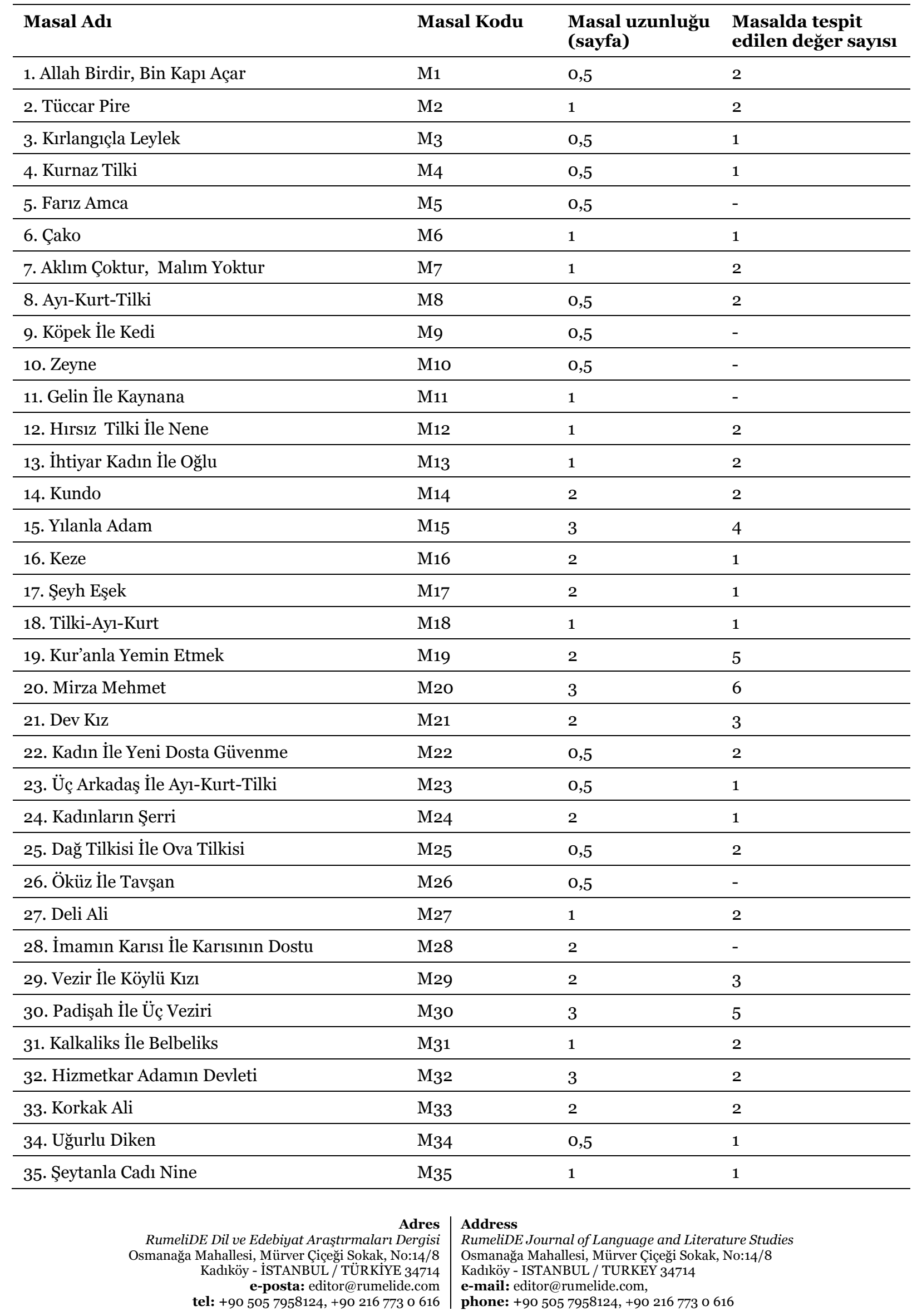


654 / RumeliDE Journal of Language and Literature Studies 2021.23 (June)

Values education in tales and legends: Sample of city of Muş / S. Aydeniz (pp. 636-659)

\begin{tabular}{|c|c|c|c|}
\hline 36. Nisko'nun Maceraları & M36 & 2 & 2 \\
\hline 37. Seyfullah İle Sadullah & M37 & 3 & 10 \\
\hline 38. Bezirgan & M38 & 3 & 12 \\
\hline 39. Cengzeri & M39 & 3 & 6 \\
\hline 40. Üç Kardeş & M40 & 2 & 3 \\
\hline 41. Ahmet Dayı & M41 & 2 & 5 \\
\hline 42. Çoban Kızı & M42 & 4 & 11 \\
\hline 43. Serfiraz İle Bikes & M43 & 3 & 13 \\
\hline 44. Peri Kızı & M44 & 3 & 9 \\
\hline 45. Satın Alınan Öğüt & M45 & 4 & 14 \\
\hline 46. Mehmet İle Mahmut & M46 & 2 & 4 \\
\hline 47. Tilki, Kurt İle Katır & M47 & 3 & 9 \\
\hline 48. Uyanık Köylü & M48 & 2 & 1 \\
\hline 49. Altın Saçlı Kız & M49 & 2 & 8 \\
\hline 50.Babasının Yerine Askerlik Yapan Kız & M50 & 3 & 14 \\
\hline 51. Kambur & $\mathrm{M}_{51}$ & 3 & 10 \\
\hline 52. Kizıl Ziyaret & M52 & 2 & 3 \\
\hline 53. Padişah ve Çiftçi & M53 & 3 & 2 \\
\hline 54. Üç Bacı & M54 & 4 & 23 \\
\hline 55. Üç Kardeş & M55 & 3 & 1 \\
\hline TOPLAM & 55 & 102 & 221 \\
\hline
\end{tabular}

\section{EK 2:}

\section{Muş Efsaneleri}

\section{Efsane Adı}

Efsane Kodu

Efsane
uzunluğu
(sayfa)

Efsanede tespit edilen değer sayısı

\begin{tabular}{llll}
\hline 1. Teğik & E1 & 0,3 & 1 \\
\hline 2. Kırmızı Tepe (GıreKozere /Gıre Sor) & E2 & 0,3 & 1 \\
\hline 3. Mercimekkale & E3 & 0,3 & - \\
\hline 4. Gelin Kayaları (KevreBuka) & E4 & 0,3 & 1 \\
\hline 5. Taş Kesilme & E5 & 0,5 & - \\
\hline 6. Anne Kayası (Kevre Daye) & E6 & 0,5 & - \\
\hline 7. Gelin Kayası (Kevre Buke) & E7 & 0,5 & - \\
\hline 8. Gelin Çeşmesi (Kaniya Buke) & E8 & 0,5 & 2 \\
\hline 9. Gelin Kayaları (KevreBuka) & E9 & 0,5 & 1 \\
\hline 10. Kocakarı Çeşmesi (Kaniya Pire) & E10 & 0,5 & 1 \\
\hline 11. Samanyolu (Kadez) & E11 & 0,3 & - \\
\hline 12. Samanyolu II & E12 & 0,3 & - \\
\hline
\end{tabular}




\begin{tabular}{|c|c|c|c|}
\hline 13. Ay ve Güneş & E13 & 0,5 & 1 \\
\hline 14. Pepuk Kuşu & E14 & 0,5 & 1 \\
\hline 15. Ayının Menşei & E15 & 0,5 & 3 \\
\hline 16. Ayının Menşei II & E16 & 0,5 & - \\
\hline 17. Devenin Menşei & E17 & 0,3 & 1 \\
\hline 18. Fare ve Kedinin Menşei & E18 & 0,5 & 2 \\
\hline 19. Gül ve Karga & E19 & 0,5 & 1 \\
\hline 20. Küçük Hamurpet Gölü & E20 & 0,3 & 1 \\
\hline 21. Büyük Hamurpet Gölü & E21 & 0,3 & 2 \\
\hline 22. Kazan Gölü & E22 & 0,5 & 1 \\
\hline 23. İnsanoğlu Üç Kısımdır & E23 & 0,3 & 1 \\
\hline 24. Kurban & E24 & 0,5 & 4 \\
\hline 25. Kurban II & E25 & 1 & 7 \\
\hline 26. Devçizoro & E26 & 0,5 & 1 \\
\hline 27. Bizden Yeğler (Je Me Çeter) & E27 & 0,5 & - \\
\hline 28. Teba & E28 & 0,5 & - \\
\hline 29. Cinlerin Düğünü & E29 & 0,5 & 1 \\
\hline 30. Talebe ile Cin & E30 & 0,5 & 5 \\
\hline 31. Elk & E31 & 1 & 1 \\
\hline 32. Pir Elk & E32 & 0,5 & 1 \\
\hline 33. ElkaFeyzo & E33 & 0,3 & 1 \\
\hline 34. Rote Şeve/ Mere Şeve & E34 & 0,3 & - \\
\hline 35. Şahmeran & E35 & 0,5 & 1 \\
\hline 36. Gimgim & E36 & 0,5 & - \\
\hline 37. Gümüşpınar Köyü’nün İsmi & E37 & 0,3 & - \\
\hline 38. Avbiri & E38 & 0,3 & 1 \\
\hline 39. Gebola Köyünün İsmi & E39 & 0,5 & 1 \\
\hline 40. Mir Hasan ve Koli Baba Dağları & $\mathrm{E} 40$ & 0,5 & - \\
\hline 41. Ağrı Dağı, Köse Dağı, Süphan Dağı & E41 & 0,3 & - \\
\hline 42. Süphan Dağı'nın Patlaması & E42 & 0,3 & 1 \\
\hline $\begin{array}{l}\text { 43. Kocakarı Günleri/ Kocakarı Fırtınası } \\
\text { (Roje Pire / Bagera Pire) }\end{array}$ & E43 & 0,3 & - \\
\hline 44. Kurdoğlu Fırtınası (Bagera Kurdoğlu) & E44 & 0,5 & - \\
\hline 45. Gameş (Camış) Kıran & E45 & 0,5 & 1 \\
\hline 46. Giskiloke Pire & E46 & 0,3 & - \\
\hline 47. Şubatok / Azbat & E47 & 0,5 & - \\
\hline 48. Mem ve Zin Gölü (GolaMem u Zine) & E48 & 0,5 & 2 \\
\hline 49. Bulanık Göl (Gola Şelü) & E49 & 0,3 & - \\
\hline 50. Yılanlar Kuyusu (Hezna Mera) & E50 & 0,3 & 1 \\
\hline \multicolumn{2}{|c|}{$\begin{array}{r}\text { Adres } \\
\text { RumeliDE Dil ve Edebiyat Arasstrmaları Dergisi } \\
\text { Osmanağa Mahallesi, Mürver Ciçeği Sokak, No:14/8 } \\
\text { Kadıköy - İSTANBUL / TÜRKiYE 34714 } \\
\text { e-posta: editor@rumelide.com } \\
\text { tel: }+905057958124,+90216773 \text { o } 616\end{array}$} & \multicolumn{2}{|c|}{$\begin{array}{l}\text { Address } \\
\text { RumeliDE Journal of Language and Literature Studies } \\
\text { Osmanağa Mahallesi, Mürver Çiçeği Sokak, No:14/8 } \\
\text { Kadıköy - ISTANBUL / TURKEY } 34714 \\
\text { e-mail: editor@rumelide.com, } \\
\text { phone: +90 505 7958124, +90 } 216773 \text { o } 616\end{array}$} \\
\hline
\end{tabular}




\begin{tabular}{|c|c|c|c|}
\hline 51. Kuruyan Çeşme & $\mathrm{E}_{51}$ & 0,5 & 1 \\
\hline 52. Gelin Çeşmesi (Kani Buke ) & $\mathrm{E} 52$ & 0,5 & 1 \\
\hline 53. Kocakarı Mağarası (Kulka Pire) & E53 & 0,3 & - \\
\hline 54. Şeyh Yakup Tepesi & E54 & 0,3 & - \\
\hline 55. Kale ve Pire & E55 & 0,3 & - \\
\hline 56. Koli Baba Dağı'ndaki Su Kanalları & E56 & 0,3 & 1 \\
\hline 57. Kızıl Ziyaret & E57 & 0,5 & 4 \\
\hline 58. Siyabend ve Hece & E58 & 0,5 & 4 \\
\hline 59. Han Aslı ile Kerem & E59 & 0,5 & 1 \\
\hline 6o. Leyl u Mecnun & E6o & 0,5 & 3 \\
\hline 61. Yarasa & E61 & 0,5 & 4 \\
\hline 62. Gavesti & E62 & 0,5 & - \\
\hline 63. Ömerî & E63 & 0,5 & - \\
\hline 64. Alp Arslan'ın Ordusu & E64 & 0,5 & 2 \\
\hline 65. Cibranlı Halit Bey (HalidBegeCibri) & E65 & 0,5 & 3 \\
\hline 66. Sultan Murat Yolu & E66 & 0,5 & 2 \\
\hline 67. Murat Köprüsü & E67 & 0,5 & 1 \\
\hline 68. İskender-i Zülkarneyn & E68 & 0,5 & - \\
\hline 69. Zernak Kalesi & E69 & 0,5 & - \\
\hline 70. Kule Reş & E70 & 0,5 & 2 \\
\hline 71. Divane Ömer & E71 & 0,3 & 1 \\
\hline 72. Mele Hasane Banokî & E72 & 0,3 & - \\
\hline 73. Şeyh Aliye Ose & E73 & 0,5 & 1 \\
\hline 74. Şeyh Bahaddin & E74 & 0,5 & 1 \\
\hline 75. Şeyh Cürruh (Cüneyd-i Abid) & E75 & 1 & 1 \\
\hline 76. Şeyh Yusuf & E76 & 0,5 & 1 \\
\hline 77. Şeyh İdris & E77 & 0,5 & - \\
\hline 78. Aynü’l Melek & E78 & 0,3 & - \\
\hline 79. Şeyh Eyübu’l Bazit Kasri & E79 & 0,3 & - \\
\hline 80. Pinediz Baba & E80 & 0,5 & 1 \\
\hline 81. Şeyh Bal & $\mathrm{E} 81$ & 0,5 & 1 \\
\hline 82. Seyyid Ahmet & $\mathrm{E} 82$ & 1 & 3 \\
\hline 83. Molla Müştak & $\mathrm{E} 83$ & 0,3 & 1 \\
\hline 84. Divane Ali & E84 & 0,5 & 1 \\
\hline 85. Şeyh Muhammede Şorike & E85 & 0,5 & 1 \\
\hline 86. Küt Baba & E86 & 0,3 & - \\
\hline 87. Hazır Baba & E87 & 0,5 & - \\
\hline 88. Seyyid Şeyh Tahir & E88 & 0,5 & 2 \\
\hline 89. Şehide Dare (Fakı Muhammed) & E89 & 0,5 & - \\
\hline \multicolumn{2}{|c|}{$\begin{array}{r}\text { Adres } \\
\text { RumeliDE Dil ve Edebiyat Araşttrmaları Dergisi } \\
\text { Osmanağa Mahallesi, Mürver Çiçeği Sokak, No:14/8 } \\
\text { Kadıköy - İSTANBUL / TÜRKIYYE 34714 } \\
\text { e-posta: editor@rumelide.com } \\
\text { tel: +90 505 7958124, +90 } 216773 \text { o } 616\end{array}$} & \multicolumn{2}{|c|}{$\begin{array}{l}\text { Address } \\
\text { RumeliDE Journal of Language and Literature Studies } \\
\text { Osmanağa Mahallesi, Mürver Çiçeği Sokak, No:14/8 } \\
\text { Kadıköy - ISTANBUL / TURKEY } 34714 \\
\text { e-mail: editor@rumelide.com, } \\
\text { phone: +90 505 7958124, +90 } 216773 \text { o } 616\end{array}$} \\
\hline
\end{tabular}




\begin{tabular}{llll}
\hline 90. Şeyh Mede Kenere & E90 & 0,5 & - \\
\hline 91. Hz. Ali’nin Dilek Taşı & E91 & 0,5 & - \\
\hline 92. Şeyh Hafız İbrahim & E92 & 0,5 & 2 \\
\hline 93. Gebelik Ağacı (Dara Hemle) & E93 & 0,5 & - \\
\hline 94.Yedi Muhammed(Heft Muhammed) & E94 & 0,5 & - \\
\hline 95. Şehide Koli Baba & E95 & 0,5 & 1 \\
\hline 96. Fekiye Teyran & E96 & 0,5 & 1 \\
\hline 97. Hızır & E97 & 0,3 & - \\
\hline 98. Hızır ve İlyas & E98 & 0,5 & 1 \\
\hline 99. Hz. Ali’nin Zülfükarı & E99 & 0,5 & 2 \\
\hline 100. Hz. İsa & E100 & 0,3 & 3 \\
\hline 101. Büyük Hamurpet Gölü & E101 & 0,3 & 1 \\
\hline TOPLAM & 101 & 46 & 105 \\
\hline
\end{tabular}

\section{EK 3:}

Malazgirt Masalları

\begin{tabular}{|c|c|c|c|}
\hline Masal Adı & Masal Kodu & $\begin{array}{l}\text { Masal uzunluğu } \\
\text { (sayfa) }\end{array}$ & $\begin{array}{l}\text { Masalda tespit } \\
\text { edilen değer sayısı }\end{array}$ \\
\hline 1. Gorso & MA1 & 2 & 2 \\
\hline 2. Sihirli Balık & MA2 & 1 & 1 \\
\hline 3. Hacı Ali & MA3 & 2 & 3 \\
\hline 4. Besmele & MA4 & 0,5 & 2 \\
\hline 5. Emanetçi & MA5 & 1 & - \\
\hline 6. Gaddar Ağanın Oğlu & MA6 & 0,5 & - \\
\hline 7. Çiftçinin Şansı & MA7 & 0,5 & - \\
\hline 8. Taş Bebek & MA8 & 0,5 & 4 \\
\hline 9. Üç Kardeşler & MA9 & 0,5 & 1 \\
\hline 10. Yemen Padişahı & MA10 & 2 & 3 \\
\hline 11. Çil Osman & MA11 & 2 & 5 \\
\hline 12. Fakir Ahmet & MA12 & 4 & 10 \\
\hline 13. Kesik Kuyruklu Tilki & MA13 & 2 & 2 \\
\hline 14. Bir Ağanın Aldığı Ders & MA14 & 1 & 3 \\
\hline 15. Ömer'in Kaderi & MA15 & 2 & 5 \\
\hline 16. Padişahın Vefasız İki Oğlu & MA16 & 2 & 3 \\
\hline 17. Eyvez & MA17 & 4 & 6 \\
\hline 18. Üç Kız Kardeş & MA18 & 2 & 4 \\
\hline 19. Kız Evladın Hikayesi & MA19 & 2 & 6 \\
\hline 20. Tembel Ali & MA2O & 2 & 2 \\
\hline 21. Sihirli Yüzük & MA21 & 3 & 8 \\
\hline $\begin{array}{r}\text { Adres } \\
\text { RumeliDE Dil ve Edebiyat Arassttrmaları Dergisi } \\
\text { Osmanağa Mahallesi, Mürver Çiçeği Sokak, No:14/8 } \\
\text { Kadıköy - İSTANBUL / TÜRKiYE 34714 } \\
\text { e-posta: editor@rumelide.com } \\
\text { tel: }+905057958124,+90216773 \text { o } 616\end{array}$ & \multicolumn{3}{|c|}{$\begin{array}{l}\text { RumeliDE Journal of Language and Literature Studies } \\
\text { Osmanağa Mahallesi, Mürver Çiçeği Sokak, No:14/8 } \\
\text { Kadıköy - ISTANBUL / TURKEY } 34714 \\
\text { e-mail: editor@ @rumelide.com, } \\
\text { phone: +90 505 7958124, +90 } 216773 \text { o } 616\end{array}$} \\
\hline
\end{tabular}


658 / RumeliDE Journal of Language and Literature Studies 2021.23 (June)

Values education in tales and legends: Sample of city of Muş / S. Aydeniz (pp. 636-659)

\begin{tabular}{|c|c|c|c|}
\hline 22. Ahmak Adam & MA22 & 2 & 5 \\
\hline 23. Hirsız Ali & MA23 & 1 & 2 \\
\hline 24. Yedi Kargalar & MA24 & 3 & 4 \\
\hline 25. Mert İle Namert & MA25 & 1 & 6 \\
\hline 26. Grarın Hikayesi & MA26 & 0,5 & 1 \\
\hline 27. Balığın Gülme Sırrı & MA27 & 2 & 3 \\
\hline 28. Bir Avuç Un & MA28 & 1 & 2 \\
\hline 29. Loş Ağa & MA29 & 1 & 3 \\
\hline 30. Yedi Ceylan & MA30 & 3 & 6 \\
\hline 31. Büyük Adam & MA31 & 2 & 8 \\
\hline 32. Kurnaz Kuş & MA32 & 0,5 & 1 \\
\hline 33. Yılanla Kurbağalar Kralı & MA33 & 0,5 & - \\
\hline 34. Zenginlik Düşü & MA34 & 0,5 & 1 \\
\hline 35. Mirza Mehame & MA35 & 1 & 1 \\
\hline 36. Korkak Adam ve Altı Dev & MA36 & 1 & - \\
\hline 37. Mercimek Oğlan & MA37 & 2 & 2 \\
\hline 38. Kayıp Hazine Avcıları & MA38 & 0,5 & 2 \\
\hline 39. Recep Ağa ve Gavur Gelin & MA39 & 1 & 2 \\
\hline 40. Horozun Alacağı & MA40 & 1 & - \\
\hline 41. Demir Çarıklar & MA41 & 1 & 5 \\
\hline 42. Tuz Değirmeni & MA42 & 0,5 & 1 \\
\hline 43. Tasa Kuşu & MA43 & 2 & 7 \\
\hline 44. Muradına Nail Olmayan Dilber & MA44 & 1 & 1 \\
\hline 45. Cimrinin Altınları & MA45 & 0,5 & 3 \\
\hline 46. Yedi Başlı Ejderha & MA46 & 2 & 3 \\
\hline 47. Deli Kadın & MA47 & 1 & 1 \\
\hline 48. Merze Muhammed & MA48 & 2 & 3 \\
\hline 49. Yedi Esrarengiz Dünya & MA49 & 2 & 3 \\
\hline 50. İyilik Kapısı & MA50 & 1 & 5 \\
\hline 51. İki Melek & MA51 & 0,5 & 2 \\
\hline 52. Yırtık Kazak & MA52 & 0,5 & 6 \\
\hline 53. Kaplumbağalı Duvar & MA53 & 1 & 3 \\
\hline 54. Akıllı Oğlan & MA54 & 2 & 8 \\
\hline 55. Kuduz Köpek & MA55 & 2 & 2 \\
\hline 56. Üç Altınlık Öğüt & MA56 & 1 & 4 \\
\hline 57. Kara Bahtlı Kız & MA57 & 1 & 3 \\
\hline 58. Ahmet İle Mehmet & MA58 & 1 & 5 \\
\hline 59. Üvey Anne & MA59 & 2 & 3 \\
\hline 6o. Derdi Olmayan Kişi & MA6o & 1 & 2 \\
\hline \multicolumn{2}{|l|}{$\begin{array}{r}\text { Osmanağa Mahallesi, Mürver } \\
\text { Kadıöy - ÍSTANI } \\
\text { e-posta: } \\
\text { tel: }+905057958\end{array}$} & \multicolumn{2}{|c|}{$\begin{array}{l}\text { Address } \\
\text { RumeliDE Journal of Language and Literature Studies } \\
\text { Osmanağa Mahallesi, Mürver Çiçeği Sokak, No:14/8 } \\
\text { Kadköy - ISTANBUL/ TURKEY } 34714 \\
\text { e-mail: editor@rumelide.com, } \\
\text { phone: +90 505 7958124, +90 } 216773 \text { o } 616\end{array}$} \\
\hline
\end{tabular}




\begin{tabular}{llll}
\hline 61. Çalışan Kazanır & MA61 & 0,5 & 1 \\
\hline 62. Mirze Muhammet & MA62 & 2 & 5 \\
\hline 63. Mem İle Memo & MA63 & 1 & 2 \\
\hline 64. Zine İle Memo & MA64 & 1 & 6 \\
\hline 65. Bir Gecede Gerçekleşen Dilekler & MA65 & 0,5 & - \\
\hline 66. Kurk Yavrulu At & MA66 & 3 & 2 \\
\hline 67. Hayırsız Evlat & MA67 & 1 & 4 \\
\hline 68. Altın Balta & MA68 & 0,5 & 2 \\
\hline 69. Cesur Ahmet & MA69 & 2 & 3 \\
\hline 70. Akıllı Çocukla Köse Değirmenciler & MA70 & 1 & 1 \\
\hline 71. Bir Şeyin Kıymetini Bilmek & MA71 & 0,5 & 3 \\
\hline 72. Şehzade İle Ceylan & MA72 & 3 & 6 \\
\hline TOPLAM & 72 & 99 & 223 \\
\hline
\end{tabular}

